\title{
Application of the ECT9 protocol for radiocarbon-based source apportionment of carbonaceous aerosols
}

\author{
Lin Huang ${ }^{1}$, Wendy Zhang ${ }^{1}$, Guaciara M. Santos ${ }^{2}$, Blanca T. Rodríguez ${ }^{2}$, Sandra R. Holden ${ }^{2}$, Vincent Vetro ${ }^{1}$, and \\ Claudia I. Czimczik ${ }^{2}$ \\ ${ }^{1}$ Climate Research Division, Atmospheric Science \& Technology Directorate, Environment and Climate Change Canada, \\ Toronto, ON M3H 5T4, Canada \\ ${ }^{2}$ Department of Earth System Science, University of California, Irvine, CA 92697-3100, USA
}

Correspondence: Lin Huang (lin.huang@canada.ca) and Claudia Czimczik (czimczik@uci.edu)

Received: 20 May 2020 - Discussion started: 4 August 2020

Revised: 22 February 2021 - Accepted: 23 February 2021 - Published: 17 May 2021

\begin{abstract}
Carbonaceous aerosol is mainly composed of organic carbon (OC) and elemental carbon (EC). Both OC and EC originate from a variety of emission sources. Radiocarbon $\left({ }^{14} \mathrm{C}\right)$ analysis can be used to apportion bulk aerosol, $\mathrm{OC}$, and EC into their sources. However, such analyses require the physical separation of OC and EC.

Here, we apply of ECT9 protocol to physically isolate OC and $\mathrm{EC}$ for ${ }^{14} \mathrm{C}$ analysis and evaluate its effectiveness. Several reference materials are selected, including two pure OC (fossil "adipic acid" and contemporary "sucrose"), two pure EC (fossil "regal black" and "C1150"), and three complex materials containing contemporary and/or fossil OC and EC ("rice char", NIST urban dust standards "SRM1649a" and "SRM8785", i.e., fine fraction of resuspended SRM1649a on filters). The pure materials were measured for their OC, EC, and total carbon (TC) mass fractions and corresponding carbon isotopes to evaluate the uncertainty of the procedure. The average accuracy of TC mass, determined via volumetric injection of a sucrose solution, was approximately $5 \%$. Ratios of EC/TC and OC/TC were highly reproducible, with analytical precisions better than $2 \%$ for all reference materials, ranging in size from 20 to $100 \mu \mathrm{g}$ C. Consensus values were reached for all pure reference materials for both $\delta^{13} \mathrm{C}$ and fraction modern $\left(\mathrm{F}^{14} \mathrm{C}\right)$, with an uncertainty of $<0.3 \%$ and approximately $5 \%$, respectively. The procedure introduced $1.3 \pm 0.6 \mu \mathrm{g}$ of extraneous carbon, an amount compatible to that of the Swiss_4S protocol.

In addition, $\mathrm{OC}$ and $\mathrm{EC}$ were isolated from mixtures of pure contemporary OC (sucrose) with pure fossil EC (regal black) and fossil OC (adipic acid) with contemporary EC
\end{abstract}

(rice char EC) to evaluate the effectiveness of OC and EC separation. Consensus $\mathrm{F}^{14} \mathrm{C}$ values were reached for all $\mathrm{OC}$ $(\sim 5-30 \mu \mathrm{g})$ and EC $(\sim 10-60 \mu \mathrm{g})$ fractions with an uncertainty of $\sim 5 \%$ on average. We found that the ECT9 protocol efficiently isolates OC or EC from complex mixtures. Based on $\delta^{13} \mathrm{C}$ measurements, the average contribution of charred OC to EC is likely less than $3 \%$ when the OC loading amount is less than $30 \mu \mathrm{g} \mathrm{C}$.

Charring was further assessed by evaluating thermograms of various materials, including aerosol samples collected in the Arctic and from tailpipes of gasoline or diesel engines. These data demonstrate that the ECT9 method effectively removes pyrolyzed OC. Thus, the ECT9 protocol, initially developed for concentration and stable isotope measurements of OC and EC, is suitable for ${ }^{14} \mathrm{C}$-based apportionment studies, including $\mu \mathrm{g} \mathrm{C}$-sized samples from arctic environments.

Copyright statement. The works published in this journal are distributed under the Creative Commons Attribution 4.0 License. This licence does not affect the Crown copyright work, which is reusable under the Open Government Licence (OGL). The Creative Commons Attribution 4.0 License and the OGL are interoperable and do not conflict with, reduce, or limit each other. (C) Crown copyright 2021

\section{Introduction}

Carbonaceous aerosol is a major component (15\%-90\%) of airborne particulate matter (PM) (Jimenez et al., 2009; 
Putaud et al., 2010; Yang et al., 2011a, b; Hand et al., 2013; Ridley et al., 2018) and is a complex mixture composed of mainly light-scattering organic carbon (OC) and highlyrefractory, light-absorbing elemental carbon (EC, also referred to as black carbon) (Pöschl, 2005). The OC and EC fractions play important and often distinct roles in climate (Bond et al., 2013; Hallquist et al., 2009; Kanakidou et al., 2005; Laskin et al., 2015), air pollution, and human health (Cohen et al., 2017; Grahame et al., 2014; Janssen et al., 2012). Moreover, both OC and EC were identified as shortlived climate forcers (SLCFs) by the IPCC expert meeting (https://www.ipcc-nggip.iges.or.jp/public/mtdocs/1805_ Geneva.html, 15 April 2021) in 2018. To develop and monitor the efficiency of mitigation strategies for both climate change and air pollution, it is required to have a better understanding of the temporal and spatial dynamics of OC and EC emission sources.

The majority ( $>50 \%$ ) of carbonaceous aerosol is OC, which has a wide size range. Coarse OC (in $\mathrm{PM}_{10}$ ) consists of plant debris, microorganisms, fungal spores, and pollen. Fine $\mathrm{OC}$ (in $\mathrm{PM}_{2.5}$ ) is formed predominantly via the oxidation or nucleation and coagulation of volatile organic compounds, such as mono- and sesquiterpenes, from both biogenic and anthropogenic sources (Shrivastava et al., 2017) but can also be directly emitted from combustion sources (Hallquist et al., 2009; Fuzzi et al., 2015; Liggio et al., 2016). In contrast, EC is found primarily in fine particles, e.g., $\mathrm{PM}_{1.0}$ or smaller (Chan et al., 2013; Bond et al., 2013). It is emitted through incomplete combustion of fossil fuels and biomass and biofuels (Bond et al., 2013; Huang et al., 2010; Evangeliou et al., 2016; Winiger et al., 2016, 2017, 2019).

Measuring the isotopic signature and composition, i.e., radiocarbon $\left({ }^{14} \mathrm{C}\right)$ content and stable isotope ratio $\left({ }^{13} \mathrm{C} /{ }^{12} \mathrm{C}\right)$ of aerosol, offers a powerful tool for quantifying the sources of bulk aerosol and its $\mathrm{OC}$ and $\mathrm{EC}$ fractions. Aerosol ${ }^{14} \mathrm{C}$ content can be used to quantify the relative contributions from contemporary biomass and fossil sources (Heal, 2014). ${ }^{14} \mathrm{C}$ is a naturally occurring radioisotope (5730 year half-life) produced in the atmosphere. After its oxidation to carbon dioxide $\left({ }^{14} \mathrm{CO}_{2}\right),{ }^{14} \mathrm{C}$ enters the food chain through photosynthesis so that all living organisms are labeled with a characteristic ${ }^{14} \mathrm{C} /{ }^{12} \mathrm{C}$ ratio and described as "modern" carbon. Materials containing carbon older than about 50000 years $\left({ }^{14} \mathrm{C} \ll{ }^{12} \mathrm{C}\right)$ are described as "fossil" carbon. Over the past centuries, the ${ }^{14} \mathrm{C}$ content of the atmosphere has undergone distinct changes (Graven, 2015; Graven et al., 2020; Levin et al., 2010): anthropogenic combustion of fossil fuels emits ${ }^{14} \mathrm{C}$-depleted carbon into the atmosphere (i.e., dilutes the proportion of ${ }^{14} \mathrm{C}$ relative to ${ }^{12} \mathrm{C}$ ). In contrast, nuclear weapons testing doubled the ${ }^{14} \mathrm{C}$ content of $\mathrm{CO}_{2}$ in the Northern Hemisphere in the mid-20th century, followed by mixing of this bomb-derived ${ }^{14} \mathrm{C}$-enriched carbon into the ocean and biosphere. Similarly, aerosol stable isotope ratios provide insight to different types of anthropogenic sources (e.g., combustion of solid and liquid vs. gaseous fossil fuels).
However, ${ }^{13} \mathrm{C}$ data cannot distinguish emissions from mixed fossil fuel combustion and live $\mathrm{C}_{3}$ plant biomass (Huang et al., 2006; Winiger et al., 2016). Thus, isotope-based source apportionment studies become particularly insightful when both ${ }^{14} \mathrm{C}$ and stable carbon isotopes are considered (Andersson et al., 2015; Winiger et al., 2016, 2017) or when combined with analyses of specific source tracers, such as levoglucosan or potassium for wood burning emissions (Szidat et al., 2006; Zhang et al., 2008) and/or remote sensing data and modeling analysis (Barrett et al., 2015; Mouteva et al., 2015b; Wiggins et al., 2018).

The objective of this study is to evaluate the effectiveness of separating OC and EC via the ECT9 (EnCan-Total900) protocol (Huang et al., 2006; Chan et al. 2010, 2019) for ${ }^{14} \mathrm{C}$-based source apportionment studies of carbonaceous aerosols. The ECT9 technique was originally developed to physically separate OC and EC mass fractions for concentration quantification and stable carbon isotope analysis. This protocol has been used since 2006 to monitor carbonaceous aerosol mass concentrations and stable isotope composition over Canada, including in the Arctic at Alert, as part of the Canadian Aerosol Baseline Measurements (CABM) Network by Environment and Climate Change Canada (Chan et al., 2010, 2019; Eckhardt et al., 2015; Sharma et al., 2017; Xu et al., 2017; Leaitch et al., 2013, 2018; Huang, 2018). It has also been used to monitor carbonaceous aerosol over China (Yang et al., 2011a, b). Furthermore, EC concentration measurements made with the ECT9 protocol correlate well with those derived from light absorption by an aethalometer and refractory black carbon (rBC) using a Single Particle Soot Photometer (SP2) (Sharma et al., 2017; Chan et al., 2019). It was demonstrated that the ECT9 protocol can be used to quantify OC/EC concentrations and provide source information at the same time.

The ECT9 protocol is a thermal evolution analysis (TEA) protocol that is different from commonly used thermal optical analysis (TOA) methods for monitoring air quality, such as the Interagency Monitoring of Protected Visual Environments (IMPROVE) protocol (Chow et al., 2001; Watson et al., 2007), the National Institute for Occupational Safety and Health protocol (NIOSH method 5040, Birch, 2002), and the European Supersites for Atmospheric Aerosol Research (EUSAAR) protocol (Cavalli et al., 2010). In those protocols, the OC fraction is thermally desorbed from filter samples in an inert helium (He) atmosphere at relatively low temperatures, and the EC fraction is combusted at higher temperatures by introducing oxygen $\left(\mathrm{O}_{2}\right)$ into the $\mathrm{He}$ stream while the filter reflectance or transmittance for a laser signal is continuously monitored. During the analysis, a fraction of the OC may char (forming pyrolyzed OC or PyOC), causing the transmittance or reflectance to decrease. While TOA methods use the changes in laser signal to mathematically correct for PyOC within the measured EC fraction, the ECT9 protocol aims to minimize or remove PyOC, together with carbonate carbon $(\mathrm{CC})$, during an intermediate temperature 
step of $870{ }^{\circ} \mathrm{C}$ in pure $\mathrm{He}$ via high-temperature evaporation (Chan et al., 2019). With much longer retention times at each temperature step (see Sect. 2) and without either reflectance or transmittance used, the ECT9 protocol effectively isolates $\mathrm{OC}, \mathrm{PyOC}+\mathrm{CC}$, and $\mathrm{EC}$.

It should be noted that other methods have been also developed mainly for ${ }^{14} \mathrm{C}$ analysis of $\mathrm{OC}$ and $\mathrm{EC}$, such as the CTO-375 (Zencak et al., 2007), the Swiss_4S protocol (Mouteva et al., 2015a; Zhang et al., 2012; Szidat et al., 2004), or hydropyrolysis (Meredith et al., 2012; Zhang et al., 2019), which use distinct temperature protocols and gas mixtures and/or remove water-soluble OC or inorganic carbon prior to EC analysis. In contrast to the ECT9 protocol, however, these approaches differ substantially from the protocols that are widely used for monitoring OC/EC mass concentrations in the field, which limits the relevance of this data for improving the representation of carbonaceous aerosols in chemical transport models.

Here we analyzed the ${ }^{14} \mathrm{C}$ content of OC and EC fractions $(<100 \mu \mathrm{g} \mathrm{C})$ isolated with the ECT9 protocol from four pure fossil and contemporary reference materials. These materials were analyzed on their own to quantify the amount and source (modern or fossil) of extraneous carbon introduced by the procedure, as well as its reproducibility. Mixtures of two reference materials were measured to elucidate how efficiently the ECT9 protocol isolates OC from EC. In addition, we investigated the laser signals of three reference materials and three aerosol samples (tailpipe emissions, ambient aerosol from Alert, and SRM8785) to assess how efficiently the ECT9 protocol removes PyOC. Our evaluation of the ECT9 protocol on its ability to physically separate OC from $\mathrm{EC}$ for ${ }^{14} \mathrm{C}$-based source apportionment studies significantly expands the existing opportunities for characterizing and monitoring sources of carbonaceous aerosol at regional or global scales while at the same time providing a solid base for $\mathrm{EC}$ and $\mathrm{OC}$ concentration measurements.

\section{Methods}

\subsection{The ECT9 protocol for the physical separation of OC and EC}

The ECT9 protocol was developed at the carbonaceous aerosol and isotope research (CAIR) lab of Environment and Climate Change Canada (ECCC) to quantify the amount of $\mathrm{OC}$ and $\mathrm{EC}$ in carbonaceous aerosol and their $\delta^{13} \mathrm{C}$ values (Huang et al., 2006; Chan et al., 2010, 2019). Carbon fractions are isolated with an OC/EC analyzer (Sunset Laboratory Inc.) coupled to a custom-made gas handling and cryogenic trapping system for $\mathrm{CO}_{2}$ collection from $\mathrm{OC}$ and $\mathrm{EC}$ fractions (Fig. 1a). The fractions are separated from each other, according to their degree of refractoriness. Specifically, carbon fractions are released by the ECT9 protocol in three steps (Fig. 1b): (1) $\mathrm{OC}$ at $550^{\circ} \mathrm{C}$ for $600 \mathrm{~s}$ in pure $\mathrm{He}$
(99.9999\% purity), (2) $\mathrm{PyOC}$ and $\mathrm{CC}$ at $870{ }^{\circ} \mathrm{C}$ for $600 \mathrm{~s}$ in pure $\mathrm{He}$, and (3) $\mathrm{EC}$ at $900{ }^{\circ} \mathrm{C}$ for $420 \mathrm{~s}$ in a mixture of $2 \%$ $\mathrm{O}_{2}$ with $98 \% \mathrm{He}$. All fractions are fully oxidized to $\mathrm{CO}_{2}$ by passing through a furnace containing $\mathrm{MnO}_{2}$ maintained at $870^{\circ} \mathrm{C}$. For concentration determination, the $\mathrm{CO}_{2}$ passes through a methanator at $500^{\circ} \mathrm{C}$, is converted to $\mathrm{CH}_{4}$, and is quantified with a flame ionization detector. For isotope analysis, the $\mathrm{CO}_{2}$ is cryo-trapped with liquid $\mathrm{N}_{2}\left(-196^{\circ} \mathrm{C}\right)$ in a $\mathrm{U}$-shaped glass trap, purified on a vacuum system (to remove $\mathrm{He}$ ), sealed into a Pyrex ampoule, and analyzed for its $\delta^{13} \mathrm{C}$ ratio with an Isotopic Ratio Mass Spectrometer (IRMS), i.e., MAT253 or $\mathrm{F}^{14} \mathrm{C}$ with an Accelerated Mass Spectrometer (AMS).

\subsection{Reference materials and their composition}

To evaluate the ECT9 method for separating OC and EC for ${ }^{14} \mathrm{C}$ analysis, we isolated and measured the ${ }^{13} \mathrm{C}$ and ${ }^{14} \mathrm{C}$ content of the OC or EC fraction or total carbon (TC) from five to six modern or fossil reference materials (Table 1), including two pure OC (adipic acid, sucrose), two EC (C1150, regal black), and two natural OC/EC mixtures (rice char and urban dust SRM1649a).

Some of the reference materials have previously been utilized to compare different protocols that quantify OC/EC fractions (Hammes et al., 2007; Willis et al., 2016) and to determine the mass of extraneous carbon introduced during OC/EC isolation from carbonaceous aerosol (Mouteva et al., 2015a). Table 1 provides an overview of their chemical compositions, i.e., total carbon contents and relative fraction of OC and EC, respectively (for individual measurements, see Table S1 in the Supplement). Primary methods (i.e., gravimetric or volumetric) are used for mass loading of the materials, whereas the mass of TC, OC, and EC are quantified via the ECT9 thermal protocol. Based on repeat injections of sucrose results (20-80 $\mu \mathrm{g}$ sucrose, $n=117)$, the accuracy of the TC mass is about $5 \%$. The reproducibilities of both $\mathrm{OC} / \mathrm{TC}$ and EC/TC percentages are $2 \%$ or better. Although uncertainties of weighing pure $\mathrm{EC}$ mass (i.e., regal black and $\mathrm{C} 1150)$ via microbalances are relatively large (due to static electricity and variable relative humidity), the $\mathrm{EC} / \mathrm{TC}$ and $\mathrm{OC} / \mathrm{TC}$ ratios for all reference materials are highly reproducible (one $\mathrm{SD}<2 \%$ ). The results show that the two EC materials (i.e., regal black and C1150) contain $97 \%$ and $98 \%$ EC, with only $3 \%$ and $2 \%$ OC, respectively. The two OC materials (i.e., sucrose and adipic acid) are $99 \%$ and $100 \%$ OC and less than $1 \%$ EC (likely due to charred OC contribution), respectively. Thus, the materials are suitable for the purpose of this study.

We also analyzed the ${ }^{13} \mathrm{C}$ and ${ }^{14} \mathrm{C}$ isotopic composition of each reference material, using offline combustions and ECT9 coupled with cryo-purification to convert them into $\mathrm{CO}_{2}$. The results are summarized in Table 2 (for individual results see Tables S2 and S3 in the Supplement). The ${ }^{14} \mathrm{C}$ analysis of $\mu \mathrm{g} \mathrm{C}$-sized carbonaceous aerosol samples requires the as- 
(a)

(1) OC/EC isolation and $\mathrm{CO}_{2}$ collection
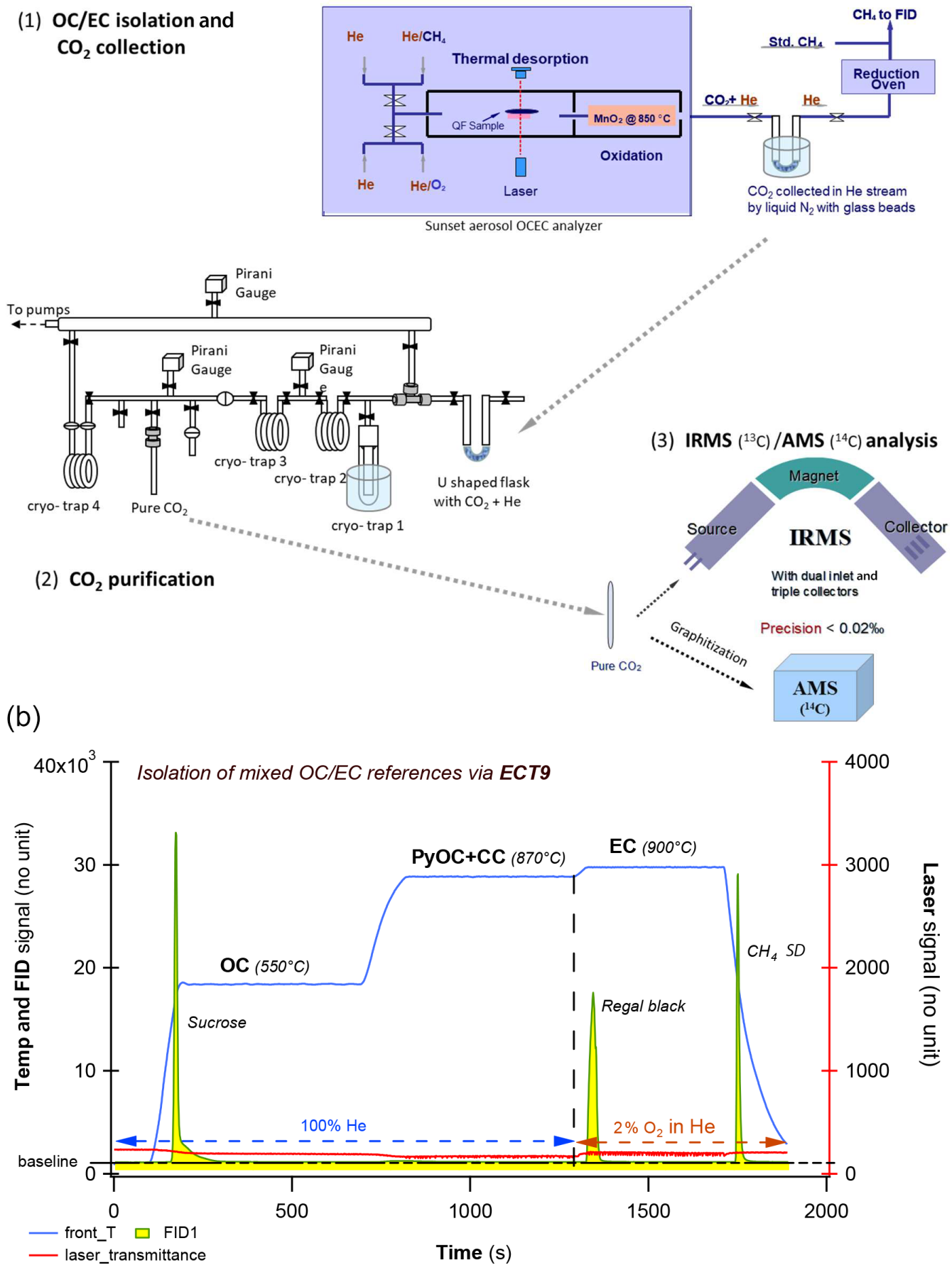

Figure 1. Overview of the carbonaceous aerosol measurements (concentration and isotopes) via EnCan-Totol-900 (ECT9). (a) Schematic procedures for ${ }^{13} \mathrm{C}$ and ${ }^{14} \mathrm{C}$ measurements of $\mathrm{OC} / \mathrm{EC}$ via ECT9, including (1) OC/EC isolation and $\mathrm{CO}_{2}$ collection via cryo-trapping, (2) $\mathrm{CO}_{2}$ purification, and (3) isotope analysis with IRMS $\left({ }^{13} \mathrm{C} /{ }^{12} \mathrm{C}\right.$ of $\left.\mathrm{CO}_{2}\right)$ or AMS $\left({ }^{13} \mathrm{C} /{ }^{12} \mathrm{C}\right.$ and ${ }^{14} \mathrm{C} /{ }^{12} \mathrm{C}$ of graphite targets). (b) Thermogram of the ECT9 protocol on a Sunset OC/EC analyzer. First, organic carbon (OC) is thermally desorbed at $550{ }^{\circ} \mathrm{C}$ for $600 \mathrm{~s}$ in $100 \%$ $\mathrm{He}$, and then any pyrolyzed OC (PyOC), refractory OC, and carbonate carbon (CC) is released at $870^{\circ} \mathrm{C}$ in $100 \% \mathrm{He}$ for $600 \mathrm{~s}$. Finally, elemental carbon (EC) is combusted at $900{ }^{\circ} \mathrm{C}$ for $420 \mathrm{~s}$ by introducing $2 \% \mathrm{O}_{2}$ in He. All carbon fractions are oxidized to $\mathrm{CO}_{2}$ followed by reduction to $\mathrm{CH}_{4}$ and quantification via flame ionization detection (FID) for carbon content or purified and cryo-trapped in Pyrex ampoules for isotope analysis. Example FID signals are shown for a pure OC reference material (sucrose) mixed with a pure EC material (regal black) and the internal standard $\left(\mathrm{CH}_{4}\right)$. 
Table 1. Overview of the bulk reference materials analyzed with the ETC9 method for their total carbon (TC), organic carbon (OC), and elemental carbon (EC) contents.

\begin{tabular}{|c|c|c|c|c|c|c|c|c|c|c|c|c|}
\hline \multirow{3}{*}{$\begin{array}{l}\text { Reference } \\
\text { material }\end{array}$} & \multicolumn{4}{|c|}{ EC } & \multicolumn{4}{|c|}{$\mathrm{OC}$} & \multicolumn{4}{|c|}{$\mathrm{EC}+\mathrm{OC}$ mixture } \\
\hline & \multicolumn{2}{|c|}{ Regal black } & \multicolumn{2}{|l|}{$\mathrm{C} 1150$} & \multicolumn{2}{|l|}{ Sucrose } & \multicolumn{2}{|l|}{ Adipic acid } & \multicolumn{2}{|c|}{ Rice char } & \multicolumn{2}{|c|}{ SRM-1649a } \\
\hline & mean & SD & mean & SD & mean & SD & mean $\quad \mathrm{S}$ & SD & mean & SD & mean & SD \\
\hline $\mathrm{TC}(\%)$ & 96 & 9 & 98 & 12 & $101^{\mathrm{a}}$ & 4 & $43^{\mathrm{b}}$ & 5 & $52^{\mathrm{c}}$ & 1 & $17.9^{\mathrm{d}}$ & 1.1 \\
\hline $\begin{array}{l}\mathrm{OC} / \mathrm{TC} \\
(\%)\end{array}$ & 3 & 1 & 1 & 2 & 99 & 1 & 100 & 0 & 14 & 1 & 51.5 & 0.8 \\
\hline $\begin{array}{l}\mathrm{EC} / \mathrm{TC} \\
(\%)\end{array}$ & 97 & 1 & 99 & 2 & 1 & 1 & $\mathbf{0}$ & 0 & 86 & 1 & 48.5 & 0.8 \\
\hline$n$ & 41 & & 24 & & 117 & & 5 & & 6 & & 6 & \\
\hline $\begin{array}{l}\text { Bulk } \\
\text { mate- } \\
\text { rial }\end{array}$ & \multicolumn{4}{|c|}{ Fine powder } & \multicolumn{2}{|l|}{ Solution } & \multicolumn{6}{|c|}{ Fine powder } \\
\hline $\begin{array}{l}\text { Loading } \\
\text { method }\end{array}$ & \multicolumn{4}{|c|}{$\begin{array}{c}\text { Gravimetric } \\
\text { (via a balance with } 1-0.1 \mu \mathrm{g} \text { accuracy) }\end{array}$} & \multicolumn{2}{|l|}{$\begin{array}{l}\text { Volumetric } \\
\text { injection }\end{array}$} & \multicolumn{6}{|c|}{$\begin{array}{c}\text { Gravimetric } \\
(1-0.1 \mu \mathrm{g} \text { accuracy })\end{array}$} \\
\hline $\begin{array}{l}\text { Loading } \\
\text { range }(\mu \mathrm{g})\end{array}$ & $16-134$ & & $4-104$ & & $20-80$ & & $30-250$ & & $70-210$ & & $440-1100$ & \\
\hline $\begin{array}{l}\text { Analysis } \\
\text { period }\end{array}$ & $2015-2017$ & & $2006,2013,2015$ & & 2013-2018 & & 2015,2019 & & 2018 & & 2004-2005 & \\
\hline Supplier & $\begin{array}{l}\text { Aerodyne R } \\
\text { MA, USA }\end{array}$ & arch, & $\begin{array}{l}\text { McMaster Univ., } \\
\text { ON, Canada }\end{array}$ & & $\begin{array}{l}\text { Sigma-Aldrich, } \\
\text { MO, USA }\end{array}$ & & $\begin{array}{l}\text { Fisher-Scientific, } \\
\mathrm{NH}, \text { USA }\end{array}$ & & $\begin{array}{l}\text { Univ. of } \\
\text { Switzerl }\end{array}$ & & NIST, MD, & \\
\hline
\end{tabular}

a The total of $101 \%$ is obtained from the ratio of TC measured to TC calculated from the injected solution of sucrose; ${ }^{\mathrm{b}}$ A total of $49 \%$ of TC to bulk material in adipic acid based on its molecular mass. ${ }^{c} \mathrm{~A}$ total of $58.6 \%$ of TC to bulk material in rice char obtained from Hammes et al. (2006). ${ }^{\mathrm{d}} \mathrm{A}$ total of $17 \%$ of TC to bulk material in SRM $1649 \mathrm{a}$ obtained from a critical evaluation of inter-laboratory data by Currie et al. (2002).

sessment of extraneous carbon (Santos et al., 2010). This is achieved by measuring multiple smaller-sized materials with known ${ }^{14} \mathrm{C}$ content. Consequently, the results in Table 2 are critical, as those ${ }^{14} \mathrm{C}$ values provide the reference for quantifying the extraneous carbon introduced during the isotope analysis procedures.

\subsection{Isolation of OC, EC, or TC with the ECT9 protocol and purification of $\mathrm{CO}_{2}$}

The isotopic analysis of carbonaceous aerosol via the ECT9 system involves three steps (Fig. 1a): (1) OC and EC isolation and $\mathrm{CO}_{2}$ collection, (2) $\mathrm{CO}_{2}$ purification, and (3) isotope analysis for either ${ }^{13} \mathrm{C} /{ }^{12} \mathrm{C}$ by IRMS or ${ }^{14} \mathrm{C}$ by AMS (i.e., coupled measurements of ${ }^{13} \mathrm{C} /{ }^{12} \mathrm{C}$ and ${ }^{14} \mathrm{C} /{ }^{12} \mathrm{C}$ of $\mu \mathrm{g} \mathrm{C}$ sized graphite targets), as desired.

The initial masses of the pure reference materials ranged from 5 to $47 \mu \mathrm{g} \mathrm{C} \mathrm{(} n=3-13$; Table S6 in the Supplement), whereas those for the mixed materials ranged from 5-30 $\mu \mathrm{g} \mathrm{C}$ for OC and 5-60 $\mu \mathrm{g}$ C for EC ( $n=5-6$; Table S7 in the Supplement). The loaded mass of each material was determined via a microbalance (MX5, Mettler Toledo or CCE6, Sartorius) with the lowest reading being 1 or $0.1 \mu \mathrm{g} \mathrm{C}$, respectively. Filters before mass loading were pre-combusted at $900^{\circ} \mathrm{C}$ in a muffle furnace overnight and wrapped into pre-fired aluminum foil before cooling below $200^{\circ} \mathrm{C}$. Usually, OC materials were first dissolved in Milli-Q water with known volume to obtain its concentration, and then a known amount
(5-10 $\mu \mathrm{L})$ of OC solution was very carefully applied onto a pre-cleaned quartz filter surface $\left(1.5 \mathrm{~cm}^{2}\right.$, Pall Canada Limited) via a syringe injection. After the injection, the quartz boat holding the punch is pushed to the right position inside of the analyzer. The volume of OC solution used does not saturate the filter but merely moistens the surface. After purging the filter for about $20 \mathrm{~min}$ ensuring the water is gone, the filter is ready for analysis. EC (i.e., regal black and C1150) and mixed materials (rice char or SRM 1649a), which cannot be completely dissolved in water, were directly weighed onto pre-cleaned quartz filter punches in the form of solids (powders). Adipic acid was also loaded as powder. The final power mass was determined by the difference weighted before and after analysis. A filter punch with the loaded mass was carefully carried to the Sunset analyzer by a Pyrex glass Petri dish with a cover for analysis with the ECT9 protocol.

OC and EC were separated and the combusted OC or EC fractions (as $\mathrm{CO}_{2}$ ) were cryo-collected in a U-shaped flask submerged in liquid $\mathrm{N}_{2}$ (Fig. 1a, step 1). Following this, the flask containing $\mathrm{CO}_{2}$ and $\mathrm{He}$ was connected to a vacuum line with four cryo-traps and several open ports (Fig. 1a, step 2), where the $\mathrm{CO}_{2}$ is purified by sequential distillation when passing cryo-traps 1 through 3 . Finally, the pure $\mathrm{CO}_{2}$ is transferred and sealed into a $6 \mathrm{~mm}$ glass ampoule for ${ }^{13} \mathrm{C}$ or ${ }^{14} \mathrm{C}$ analysis. Pressure is read by a Pirani gauge before sealing the ampoule for an estimation of the amount of gas, and consequently sample size could be determined as $\mu \mathrm{gC}$. 
Table 2. Overview of the isotopic composition of the reference materials used in this study. Radiocarbon $\left({ }^{14} \mathrm{C} /{ }^{12} \mathrm{C}\right.$, reported as fraction modern, $\mathrm{FM}^{14} \mathrm{C}$ ) was measured at the KCCAMS facility, and $\delta^{13} \mathrm{C}$ was measured at the CAIR lab.

\begin{tabular}{|c|c|c|c|c|c|c|c|c|c|c|c|c|}
\hline \multirow[t]{2}{*}{ Reference material } & \multicolumn{4}{|c|}{$\mathrm{EC}$} & \multicolumn{4}{|c|}{$\mathrm{OC}$} & \multicolumn{4}{|c|}{$\mathrm{EC}+\mathrm{OC}$ mixture } \\
\hline & \multicolumn{2}{|c|}{$\begin{array}{l}\text { Regal black } \\
\text { mean SD }\end{array}$} & $\begin{array}{l}\mathrm{C} 1 \\
\text { mean }\end{array}$ & $\mathrm{SD}$ & \multicolumn{2}{|c|}{ Sucrose } & \multicolumn{2}{|c|}{ Adipic acid } & $\begin{array}{l}\text { Rice } \\
\text { mean }\end{array}$ & har & $\begin{array}{l}\text { SRM- } \\
\text { mean }\end{array}$ & SD \\
\hline \multicolumn{13}{|l|}{${ }^{14} \mathrm{C}$ analysis } \\
\hline $\begin{array}{l}\mathrm{FM}^{14} \mathrm{C}_{-} \mathrm{TC} \\
n \\
\text { Loading range }(\mu \mathrm{g})\end{array}$ & $\begin{array}{r}-0.0001 \\
2 \\
700-750\end{array}$ & 0.0006 & $\begin{array}{r}0.0027 \\
3 \\
60-560\end{array}$ & 0.0008 & $\begin{array}{r}1.0586 \\
2 \\
730-770\end{array}$ & 0.0016 & $\begin{array}{r}0.0000 \\
5 \\
740-1050\end{array}$ & 0.0002 & $\begin{array}{r}1.0675 \\
3 \\
900-960\end{array}$ & 0.0007 & $\begin{array}{r}0.5118 \\
1 \\
760\end{array}$ & 0.001 \\
\hline $\begin{array}{l}\mathrm{CO}_{2} \text { isolation and } \\
{ }^{14} \mathrm{C} /{ }^{12} \mathrm{C} \text { analysis }\end{array}$ & \multicolumn{12}{|c|}{$\begin{array}{l}\text { Reference material is combusted in } 6 \mathrm{~mm} \text { O.D. quartz tubes with } 80 \mathrm{mg} \mathrm{CuO} \text { for } 3 \mathrm{~h} \text { at } 900^{\circ} \mathrm{C} \text {. } \\
\text { Sample } \mathrm{CO}_{2} \text { is purified cryogenically and reduced to graphite (Xu et al., 2007). }\end{array}$} \\
\hline \multicolumn{13}{|l|}{$\delta^{13} \mathrm{C}$ analysis } \\
\hline $\begin{array}{l}\delta^{13} \mathrm{C}_{\mathrm{VPDB}}(\% \circ) \\
n \\
\text { Loading range } \\
\left(\mu \mathrm{g} \text { or } \mu \mathrm{g} \mathrm{C}^{*}\right)\end{array}$ & $\begin{array}{r}-27.61 \\
5 \\
15-70\end{array}$ & 0.08 & $\begin{array}{r}-23.06 \\
5 \\
20-50\end{array}$ & 0.08 & $\begin{array}{r}-12.22 \\
9 \\
20\end{array}$ & 0.16 & $\begin{array}{l}\mathrm{n} / \mathrm{a} \\
\mathrm{n} / \mathrm{a} \\
\mathrm{n} / \mathrm{a}\end{array}$ & & $\begin{array}{r}-26.74 \\
1 \\
160\end{array}$ & & $\begin{array}{r}-25.84 \\
2 \\
600\end{array}$ & 0.07 \\
\hline $\mathrm{CO}_{2}$ isolation & \multicolumn{6}{|c|}{$\begin{array}{l}\text { Material is loaded on a quartz filter and combusted in a } \\
\text { Sunset OC/EC aerosol analyzer (http://www.sunlab.com, } \\
\text { last access: } 19 \text { April 2021) using the ECT9 method. } \\
\text { Sample } \mathrm{CO}_{2} \text { is collected in a U-shaped flask submerged in } \\
\text { liquid } \mathrm{N}_{2} \text { at }-196^{\circ} \mathrm{C} \text { (Fig. 1b). }\end{array}$} & $\mathrm{n} / \mathrm{a}$ & & \multirow{2}{*}{\multicolumn{4}{|c|}{$\begin{array}{l}\text { See description for regal black, C1150, } \\
\text { and sucrose. }\end{array}$}} \\
\hline $\begin{array}{l}\mathrm{CO}_{2} \text { extraction and } \\
{ }^{13} \mathrm{C} /{ }^{12} \mathrm{C} \text { analysis }\end{array}$ & $\begin{array}{l}\text { Sample C } \\
\text { and sealed } \\
\text { Isotopic } \mathrm{R}\end{array}$ & $\begin{array}{l}2 \text { is cryo } \\
\text { into an a } \\
\text { tio Mass }\end{array}$ & $\begin{array}{l}\text { enically } p \\
\text { ipoule for } \\
\text { Spectrome }\end{array}$ & $\begin{array}{l}\text { rified on } \\
\text { inalysis } \mathrm{w} \\
\text { er (Huans }\end{array}$ & $\begin{array}{l}\text { vacuum lin } \\
\text { th a MAT2 } \\
\text { et al., } 2013\end{array}$ & & $\mathrm{n} / \mathrm{a}$ & & & & & \\
\hline
\end{tabular}

* Sucrose was loaded as a solution ( $\mu \mathrm{g}$ C), and regal black, C1150, adipic acid, rice char, and SRM-1649a were loaded as a fine powder ( $\mu \mathrm{g}$ dry mass); n/a stands for not applicable

\section{$2.4{ }^{14} \mathrm{C}$ measurements}

At the KCCAMS facility, the OC and EC fractions or TC (in form of $\mathrm{CO}_{2}$ ) were reduced to graphite on iron powder via hydrogen $\left(\mathrm{H}_{2}\right)$ reduction using equipment and protocols specifically developed for smaller-sized $(\leq 15 \mu \mathrm{g} \mathrm{C})$ samples (Santos et al., 2007a, b). Briefly, sample- $\mathrm{CO}_{2}$ was introduced into a vacuum line, cryogenically isolated from any water vapor, monometrically quantified, and then transferred to a heated reaction chamber, where it was mixed with $\mathrm{H}_{2}$ and reduced to filamentous graphite. To characterize the graphitization, handling, and AMS analysis, two relevant standards (oxalic acid II as modern carbon and adipic acid as fossil carbon), with similar size ranges to the samples prepared via ECT9, were also processed into graphite. The graphite was then pressed into aluminum holders and loaded into the AMS unit alongside measurement standards (Table S6) and blanks for ${ }^{14} \mathrm{C}$ measurement (Beverly et al., 2010). The data are reported as a fraction of modern carbon $\left(\mathrm{F}^{14} \mathrm{C}\right)$, following the conventions established by Stuiver and Polach (1977) and also described elsewhere (Reimer et al., 2004; Trumbore et al., 2016).

To establish consensus values (Table 2), we also analyzed the ${ }^{14} \mathrm{C}$ content of the bulk reference materials ranging in size from 0.06 to $1 \mathrm{mgC}$, using our standard combustion and graphitization methods. Larger aliquots of material were weighed into a pre-combusted quartz tube with $80 \mathrm{mg} \mathrm{CuO}$, evacuated, and combusted at $900{ }^{\circ} \mathrm{C}$ for $3 \mathrm{~h}$. The resulting $\mathrm{CO}_{2}$ was cryogenically purified on a vacuum line, reduced to graphite using a closed-tube zinc-reduction method (Xu et al., 2007), and analyzed as described above.

\subsection{Quantification of extraneous carbon}

Any type of sample processing and analysis introduces extraneous carbon $\left(\mathrm{C}_{\mathrm{ex}}\right)$. Therefore, the measured mass of any sample will include the mass of this sample and of any $\mathrm{C}_{\mathrm{ex}}$ incorporated throughout the analysis (Eq. 1):

$m_{\text {spl_meas }}=m_{\mathrm{spl}}+m_{\mathrm{ex}}$,

where $m_{\mathrm{spl} \_m e a s}, m_{\mathrm{spl}}$, and $m_{\mathrm{ex}}$ are the measured and theoretical mass of the sample and of $\mathrm{C}_{\mathrm{ex}}$, respectively. For small samples (with a mass of a few $\mu \mathrm{gC}$ ), the mass of $\mathrm{C}_{\mathrm{ex}}$ can compete with or overwhelm the sample mass and cause the measured $\mathrm{F}^{14} \mathrm{C}$ value of a sample to deviate from its consensus value.

Here, we estimated the mass of $\mathrm{C}_{\mathrm{ex}}$ introduced during the ECT9 protocol and the ${ }^{14} \mathrm{C}$ analysis following Santos et al. (2010), where $C_{\mathrm{ex}}$ is understood to consist of a modern and of fossil component (Eq. 2):

$m_{\mathrm{ex}}=m_{\mathrm{mex}}+m_{\mathrm{fex}}$,

where $m_{\text {mex }}$ and $m_{\text {fex }}$ is the mass of the modern and fossil $\mathrm{C}_{\mathrm{ex}}$, respectively. 
Following an isotope mass balance approach, the measured isotopic ratio $\left({ }^{14} \mathrm{C} /{ }^{12} \mathrm{C}\right)$ of a sample $\left(R_{\text {spl_meas }}\right)$ can be expressed as Eq. (3).

$$
R_{\text {spl_meas }}=\frac{m_{\mathrm{spl}} R_{\mathrm{spl}}+m_{\mathrm{mex}} R_{\mathrm{m}}+m_{\mathrm{fex}} R_{\mathrm{f}}}{m_{\text {spl_meas }}},
$$

where $R_{\mathrm{spl}}$ is the theoretical isotopic ratio of the sample, and $R_{\mathrm{m}}$ and $R_{\mathrm{f}}$ are the consensus isotopic ratios of a modern and fossil standard, respectively. This equation can be further simplified because $R_{\mathrm{f}}$ is $0 . R_{\mathrm{m}}$ is determined by measuring regular-sized aliquots of this reference material. In addition, all ${ }^{14} \mathrm{C} /{ }^{12} \mathrm{C}$ ratios are corrected for isotope fractionation using their $\delta^{13} \mathrm{C}$ measured alongside ${ }^{14} \mathrm{C}$ on the AMS (Beverly et al., 2010).

The mass of modern $\mathrm{C}_{\mathrm{ex}}$ can be quantified by analyzing fossil reference materials, which are highly sensitive to modern pollutants and insensitive to fossil pollutants. Based on Eq. (3), the measured isotopic ratio of the fossil reference ( $\left.R_{\mathrm{f} \_ \text {meas }}\right)$ can be expressed as Eq. (4):

$R_{\mathrm{f} \_ \text {meas }}=\frac{m_{\text {mex }} R_{\mathrm{m}}}{m_{\text {spl_meas }}}$.

The smaller the mass of the fossil reference material, the greater the effect of the constant mass of modern $\mathrm{C}_{\mathrm{ex}}$ on the isotope ratio of the fossil reference material, i.e., $R_{\mathrm{f} \_ \text {meas }}$ deviates toward $R_{\mathrm{m}}$.

Similarly, the mass of fossil $\mathrm{C}_{\mathrm{ex}}$ can be quantified by analyzing modern reference materials. With decreasing mass, the measured isotopic ratio of the modern reference $\left(R_{\mathrm{m} \_m e a s}\right)$ will deviate more strongly from $R_{\mathrm{m}}$ (toward $R_{\mathrm{f}}$ ). Based on Eqs. (1)-(3) and assuming $m_{\mathrm{spl}} \gg m_{\mathrm{mex}}$, the $R_{\mathrm{m} \_ \text {meas }}$ can be expressed as Eq. (5):

$R_{\mathrm{m} \_ \text {meas }}=\frac{m_{\mathrm{spl}} R_{\mathrm{m}}+m_{\mathrm{mex}} R_{\mathrm{m}}}{m_{\mathrm{spl} \_ \text {meas }}} \approx \frac{\left(m_{\text {spl_meas }}-m_{\mathrm{fex}}\right) R_{\mathrm{m}}}{m_{\text {spl_meas }}}$.

Finally, we can calculate the $C_{\mathrm{ex}}$-corrected isotope ratio of an unknown sample ( $\left.F_{\text {spl_cor }}\right)$. This value is reported as the ratio between the theoretical isotopic ratio of this sample and the accepted value of a modern standard $\left(R / R_{\mathrm{m}}\right)$, also known as "fraction modern" ( $F$; with all $R$ corrected for stable isotope fractionation). This data are reported as Eq. (6):

$$
\begin{aligned}
F_{\text {spl_cor }}=\frac{R_{\mathrm{spl}}}{R_{\mathrm{m}}} & \approx \frac{R_{\text {spl_meas }}-R_{\mathrm{f} \_ \text {meas }}}{R_{\mathrm{m} \_ \text {meas }}-R_{\mathrm{f} \_ \text {meas }}} \\
& \approx F_{\mathrm{m} *} \cdot \frac{\left[\frac{R_{\text {spl_meas }}}{R_{\mathrm{m}}}-\frac{m_{\text {mex }}}{m_{\text {spl_meas }}}\right]}{\left[1-\frac{m_{\text {mex }}}{m_{\text {spl_meas }}}-\frac{m_{\text {fex }}}{m_{\text {spl_meas }}}\right]},
\end{aligned}
$$

where $F_{\mathrm{m} *}$ is determined from the direct measurement of the modern primary reference material (OX1) used to produce six time-bracketed graphite targets measured in a single batch after isotopic fractionation correction and normalization (Santos et al., 2007a,b). The individual uncertainty of
$F_{\text {spl_cor }}$ is determined from counting statistics and by propagating the quantified blanks using a mass balance approach. Long-term and continuous measurements of various types of blanks indicate that the mass of $\mathrm{C}_{\mathrm{ex}}$ within one analytical method or system can vary as much as $50 \%$ (see Santos et al., 2010; Fig. 1). Therefore, we applied a $50 \%$ error in $m_{\mathrm{fex}}$ and $m_{\text {mex }}$ from long-term measurements of variance in $m_{\mathrm{ex}}$ of small samples (Santos et al., 2007a).

In this study, we used a multi-step approach to quantify $m_{\text {ex }}$ introduced by the ECT9 protocol and ${ }^{14} \mathrm{C}$ analysis (i.e., graphite target preparation for $\mathrm{CO}_{2}$ sample plus AMS analysis). First, we quantified $m_{\mathrm{ex}}$ introduced during ${ }^{14} \mathrm{C}$ sample preparation and analysis by analyzing different masses of our bulk reference materials without involving ECT9 protocol. Extraneous carbon is introduced during sealed tube combustion and graphitization followed by graphite target handling and AMS measurement at the KCCAMS facility. Typically, ${ }^{14} \mathrm{C}$ sample preparation and AMS measurement contributes a small portion to $m_{\mathrm{ex}}$ (Mouteva et al., 2015a; Santos et al., 2010). Second, we quantified the portion of $m_{\mathrm{ex}}$ added during the isolation of OC and EC with the ECT9 protocol. This portion of $m_{\mathrm{ex}}$ allows us to determine the practical minimum sample size limit for the entire method, including $m_{\mathrm{ex}}$ contributions from filter handling before $\mathrm{OC} / \mathrm{EC}$ analysis, instrument separation, and transfer to the cryo-collection system and Pyrex ampoules. To isolate this portion, we quantified $m_{\text {ex }}$ of the entire procedure (ECT9 protocol plus ${ }^{14} \mathrm{C}$ analysis) by analyzing the ${ }^{14} \mathrm{C}$ signature of $\mathrm{OC}$ and $\mathrm{EC}$ from different masses of a large set of reference materials and then subtracted the portion of $m_{\mathrm{ex}}$ introduced during ${ }^{14} \mathrm{C}$ analysis.

\section{Results and discussion}

\subsection{Recovery estimation}

The reference materials used in this study, including the modern and fossil end-members (i.e., the major carbon sources) found in carbonaceous aerosol and their TC, OC, and EC concentrations are shown in Table 1. Reference materials were separated into OC, EC, or TC using the ECT9 method at ECCC's CAIR lab (Fig. 1) and analyzed for their ${ }^{14} \mathrm{C}$ content at UC Irvine's KCCAMS facility, including graphitization and AMS analysis.

Figure 2 shows the cross-validation of carbon mass between the mass determined at ECCC's CAIR lab and the mass quantified at UC Irvine's KCCAMS lab indicating a very good positive correlation $\left(R^{2}=0.93\right.$ for pure materials and $R^{2}=0.95$ for two-material-mixtures in Fig. $2 \mathrm{a}$ and b, respectively). Reassessment of sample masses by manometric measurements at UC Irvine (UCI) show good agreement with initial mass loaded at ECCC's CAIR lab via gravimetric or volumetric methods (Fig. 2a and b and Tables S6 and S7). It is suggested that no major losses or gains of carbon occurred 

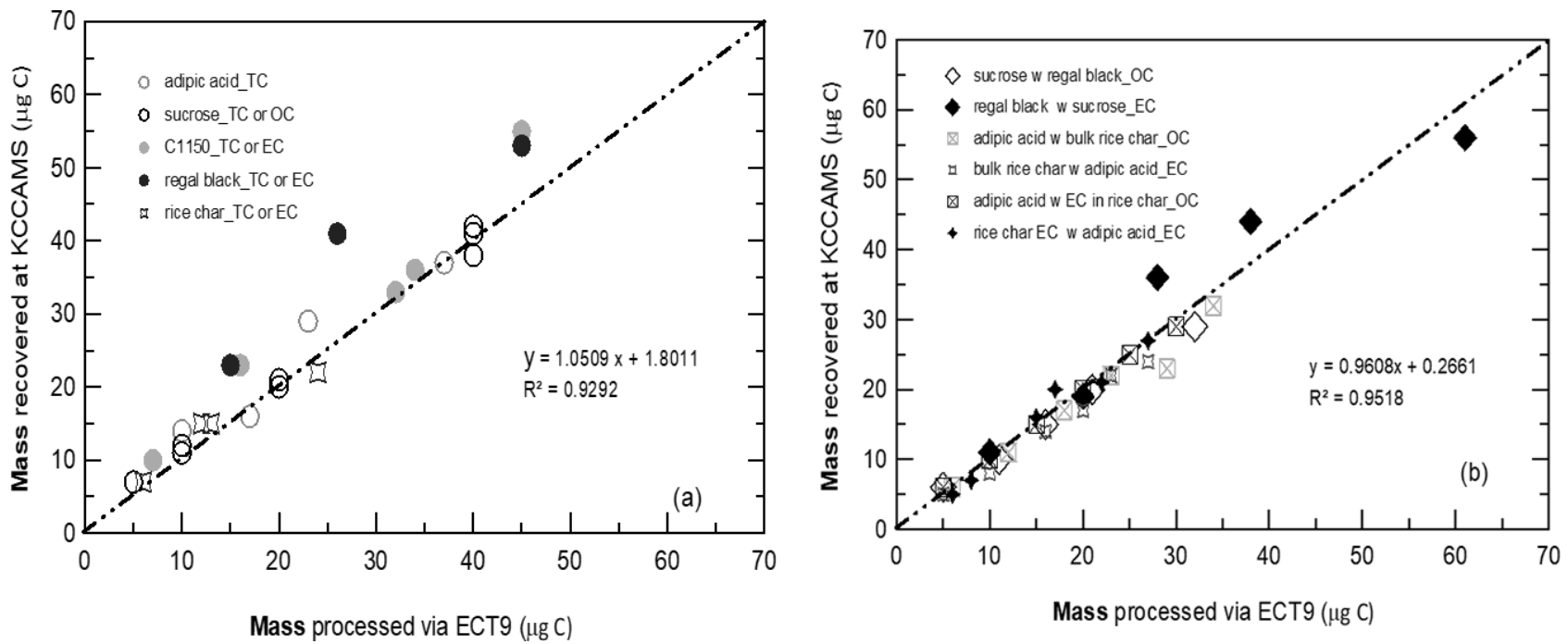

Figure 2. Cross-validation of carbon mass processed by the ECT9 protocol and collected via cryo-trapping at ECCC and the carbon mass retrieved during the purification and graphitization on a KCCAMS vacuum line. Carbon fractions (OC, EC, or TC) were isolated from two reference materials for OC (sucrose, adipic acid) and for EC (regal black, C1150) and one OC and EC mixture (rice char). Most of the points deviating from the $1: 1$ line are carbon-rich reference materials, e.g., regal black and $\mathrm{C} 1150$ (>90\% TC), wherein there are usually greater uncertainties in initial mass determination via weighing using microbalance.
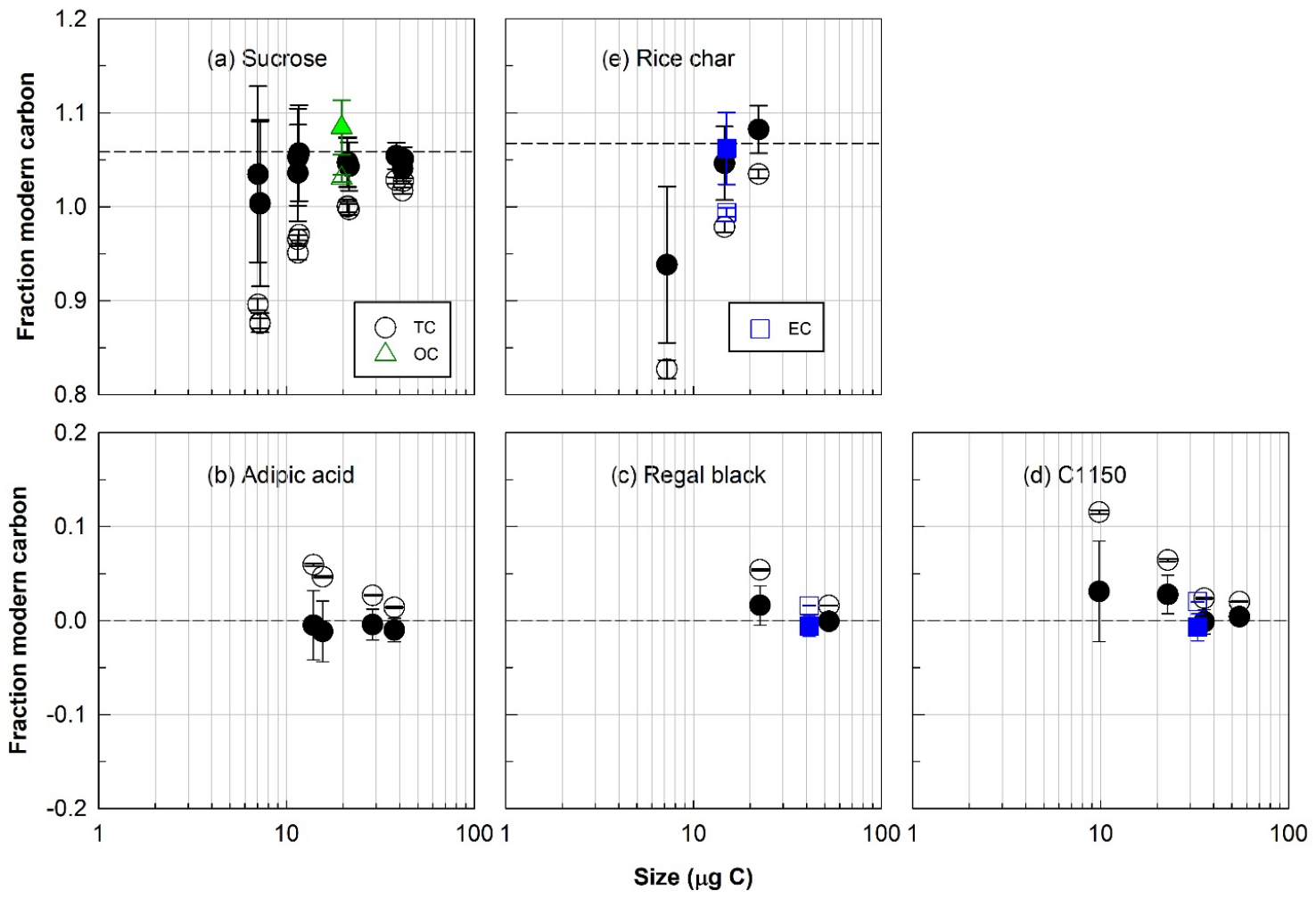

Figure 3. Radiocarbon $\left({ }^{14} \mathrm{C}\right)$ compositions, expressed as fraction of modern carbon, total carbon (TC, circles), organic carbon (OC, triangles), and elemental carbon (EC, squares) isolated with the ECT9 protocol from individual modern or fossil reference materials. (a) Sucrose and (b) adipic acid are modern and fossil OC, respectively; (c) regal black and (d) C1150 are fossil EC; and (e) rice char is a mixture of modern $\mathrm{OC}$ and EC. Open and solid symbols represent ${ }^{14} \mathrm{C}$ data before and after correction for extraneous carbon introduced during OC/EC isolation and subsequent ${ }^{14} \mathrm{C}$ analysis, respectively. The dashed line indicates the consensus value determined from regular-sized bulk samples of these materials undergoing offline combustions (see Table 2). 
Table 3. Comparison of the OC and EC ECT9 and Swiss-4S isolation protocols.

\begin{tabular}{|c|c|c|c|c|}
\hline Carrier gas & Carbon fraction & Temperature $\left({ }^{\circ} \mathrm{C}\right)$ & Duration (s) & Comments \\
\hline \multicolumn{5}{|l|}{ ETC9 $^{\mathrm{a}}$} \\
\hline He purge & & $20-50$ & 90 & Purging of volatile and semi-volatile OC \\
\hline $\mathrm{He}$ & $\mathrm{OC}$ & 550 & 600 & \\
\hline $\mathrm{He}$ & $\mathrm{PyOC}+\mathrm{CC}$ & 870 & 600 & Minimizing charred OC contribution to EC \\
\hline $\mathrm{O}_{2} / \mathrm{He}^{\mathrm{b}}$ & $\mathrm{EC}$ & 900 & 420 & \\
\hline \multicolumn{5}{|l|}{ Swiss- $4 S^{c}$} \\
\hline $\mathrm{O}_{2}$ purge & & $20-50$ & 90 & Purging of volatile and semi-volatile OC \\
\hline $\mathrm{O}_{2}$ & S1_OC & 375 & 240 & \\
\hline $\mathrm{O}_{2}$ & S2_OC & 475 & 120 & \\
\hline $\mathrm{He}$ & S3_OC & 650 & 180 & \\
\hline $\mathrm{O}_{2}$ & S4_EC & 760 & 160 & $\begin{array}{l}\text { Water-soluble OC is removed by water extraction prior to ther- } \\
\text { mal analysis }\end{array}$ \\
\hline
\end{tabular}

${ }^{a}$ PyOC $+\mathrm{CC}=$ pyrolysis OC + carbonate carbon. ${ }^{b}$ The flow of $10 \% \mathrm{O}_{2}+90 \% \mathrm{He}$ mixing with the flow of $100 \% \mathrm{He}$, resulting in $2 \%$ O $2+98 \% \mathrm{He} .{ }^{\mathrm{c}}$ The EC punch is flushed with Milli-Q water prior the analysis to remove the water-soluble OC and minimize charring (Zhang et al., 2012; Mouteva et al., 2015a).

during the entire analytical process and the overall recovery was close to $100 \%$, with a $5 \%$ uncertainty for samples ranging in size from about 5 to $60 \mu \mathrm{g} \mathrm{C}$.

\subsection{Quantification of extraneous carbon and its sources}

All types of samples, regardless of size, show deviations in their measured $\mathrm{F}^{14} \mathrm{C}$ value from their consensus values to certain degree due to $\mathrm{C}_{\mathrm{ex}}$ introduced during sample analysis. In $\mu$ g C-sized samples (mass $<15 \mu \mathrm{g} \mathrm{C}$ ), significant bias from any $\mathrm{C}_{\mathrm{ex}}$ can be observed because $\mathrm{C}_{\mathrm{ex}}$ constitutes a large fraction of the total sample. Previous work (using solventfree analytical protocols) has shown that modern $\mathrm{C}_{\mathrm{ex}}$ is introduced mostly through instrumentation and sample handling techniques, while fossil $\mathrm{C}_{\mathrm{ex}}$ originates from iron oxide used as a catalyst for the reduction of $\mathrm{CO}_{2}$ to graphite prior to AMS analysis (Santos et al., 2007a, b).

The $\mathrm{F}^{14} \mathrm{C}$ values of the pure modern or fossil reference materials generally agreed with their accepted $\mathrm{F}^{14} \mathrm{C}$ values for both OC and EC fractions (within approximately $5 \%$ uncertainty on average; see Fig. 3 and Table 2, S6, and S7) after applying a constant amount $\mathrm{C}_{\mathrm{ex}}$ correction in $\mathrm{F}^{14} \mathrm{C}$ determination. Specifically, the overall agreements for all individual pure (Table S6) and mixed reference materials (Table $\mathrm{S} 7$, excluding the $\mathrm{OC}$ data from adipic acid + bulk rice char) are within $2 \pm 3 \%$ of their corresponding values (Table 2). On average, for samples containing $>10 \mu \mathrm{g} \mathrm{C}$ the agreements are within $1 \pm 1 \%$, whereas samples containing between $>5 \mu \mathrm{g} \mathrm{C}$ and $<10 \mu \mathrm{g} \mathrm{C}$ are around $7 \pm 5 \%$. This constant $\mathrm{C}_{\mathrm{ex}}$ is a critical prerequisite for accurately correcting the $\mathrm{F}^{14} \mathrm{C}$ value of unknown samples. Hence, our data demonstrated that the ECT9 method (and subsequent ${ }^{14} \mathrm{C}$ analysis) introduces a small, reproducible amount of $\mathrm{C}_{\mathrm{ex}}$.

According to Eqs. (4) and (5) in Sect. 2.5, $\mathrm{C}_{\mathrm{ex}}$ can be quantified by measuring $\mathrm{F}^{14} \mathrm{C}$ of pure modern or fossil materi- als with different sizes. Figure 3 demonstrates that regardless what ${ }^{14} \mathrm{C}$ content is in carbon fractions isolated from the reference materials and what size it is, the corrected $\mathrm{F}^{14} \mathrm{C}$ values match with the consensus value within propagated uncertainty.

To evaluate the suitability of ECT9 for ${ }^{14} \mathrm{C}$ analysis of aerosol samples, a comparison is made between the results of a published method (i.e., Swiss_4S) and those of ECT9. The two protocols are listed in Table 3 , and their $\mathrm{C}_{\mathrm{ex}}$ distribution is shown in Table 4. The total amount of $\mathrm{C}_{\mathrm{ex}}$ introduced by the complete procedure through ECT 9 and determined based on all reference materials was $1.3 \pm 0.6 \mu \mathrm{g} \mathrm{C}$, with $70 \%$ originating from contamination with modern carbon (Table 4). The isolation of OC and EC with the ECT9 protocol introduced $65 \%$ of total $\mathrm{C}_{\mathrm{ex}}(0.85$ out of $1.35 \mu \mathrm{g} \mathrm{C})$, with $65 \%$ derived from modern carbon. Overall, the total amount of $\mathrm{C}_{\mathrm{ex}}$ introduced during $\mathrm{OC} / \mathrm{EC}$ isolation with the ECT9 protocol is comparable to that for the Swiss_4S protocol established at UCI within uncertainties (Table 3, Mouteva et al., 2015a). Thus, it is demonstrated that the ECT9 protocol serves as a suitable alternative for the ${ }^{14} \mathrm{C}$ analysis of aerosol samples with masses $>5 \mu \mathrm{g} \mathrm{C}$.

\subsection{Effectiveness of OC/EC separation}

To investigate the effectiveness of the ECT9 for separating $\mathrm{OC}$ from EC in more complex mixtures while minimizing OC into the EC fraction via pyrolysis, mixtures of the modern and fossil reference materials (Table 2) were used for measuring $\delta^{13} \mathrm{C}$ (Tables $\mathrm{S} 4$ and $\mathrm{S} 5$ in the Supplement) and $\mathrm{F}^{14} \mathrm{C}$ (Table S7).

First, it was found that the $\mathrm{F}^{14} \mathrm{C}$ values of $\mathrm{OC}$ and $\mathrm{EC}$ fractions isolated from mixtures of pure sucrose (modern OC) and pure regal black (fossil EC) were within the measurement uncertainty of their accepted $\mathrm{F}^{14} \mathrm{C}$ values after correc- 

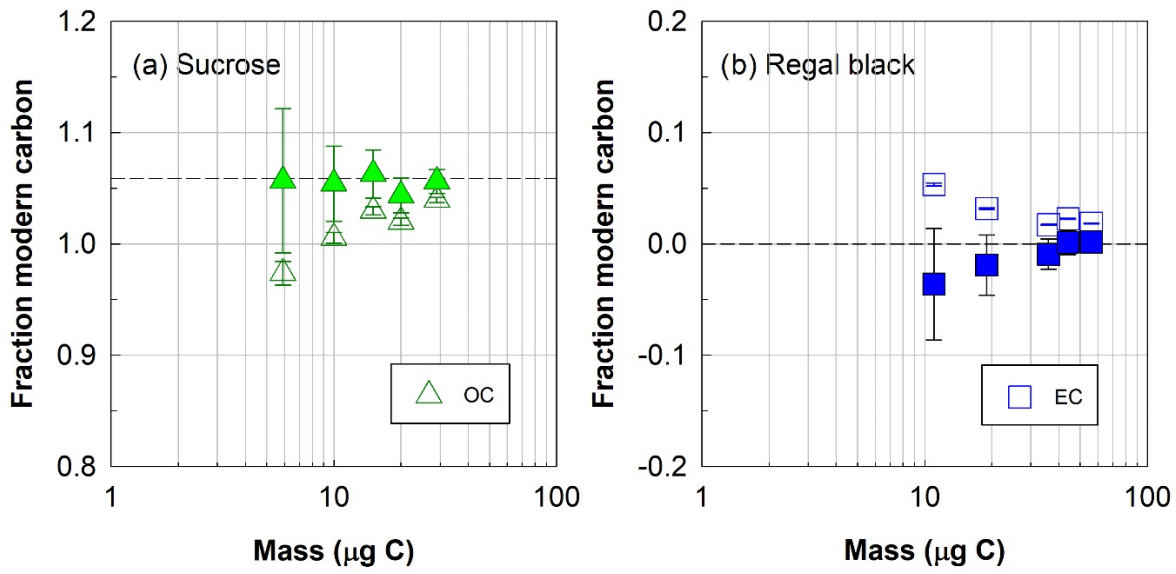

Figure 4. Radiocarbon $\left({ }^{14} \mathrm{C}\right)$ composition, expressed as fraction of modern carbon, of (a) organic (OC, triangles) or (b) elemental (EC, squares) carbon fractions isolated with the ECT9 protocol from mixtures of pure modern OC (sucrose) with fossil EC (regal black). Open and solid symbols represent ${ }^{14} \mathrm{C}$ data before and after correction for extraneous carbon introduced during OC/EC isolation via ECT9 and subsequent ${ }^{14} \mathrm{C}$ analysis via AMS, respectively (see Table S7). The dashed line indicates the consensus value (see Table 2).

Table 4. Comparison of the procedural contamination with extraneous carbon for aerosol reference materials partitioned into organic carbon (OC) and elemental carbon (EC) with the ECT9 or Swiss_4S protocols based on their ${ }^{14} \mathrm{C}$ contents. We assume a measurement uncertainty of $50 \%$ (see Sect. 2).

\begin{tabular}{lcc}
\hline Contamination Source & $\begin{array}{r}\text { ECT9 } \\
\mu \mathrm{g} \mathrm{C}\end{array}$ & Swiss_4S $^{\mathrm{a}}$ \\
\hline OC/EC isolation + trapping & & \\
\hline Modern & 0.55 & 0.37 \\
Fossil & 0.30 & 0.13 \\
Total & 0.85 & 0.50 \\
\hline${ }^{14} \mathrm{C}$ analysis ${ }^{\mathrm{b}}$ & & \\
\hline Modern & & \\
Fossil & 0.35 & 0.43 \\
Total & 0.10 & 0.53 \\
& 0.45 & 0.97 \\
\hline Full set-up & & \\
\hline Modern & & 0.80 \\
Fossil & 0.90 & 0.67 \\
Total & 0.40 & 1.47 \\
\hline
\end{tabular}

${ }^{a}$ From Mouteva et al. (2015a). ${ }^{b}$ Carbon introduced during sample combustion, $\mathrm{CO}_{2}$ purification and graphitization, and measurement with ${ }^{14} \mathrm{C}$ AMS

tion for a constant amount of $\mathrm{C}_{\mathrm{ex}}$ (Fig. 4) for samples with 5$34 \mu \mathrm{g}$ OC carbon and 10-60 $\mu \mathrm{g}$ EC carbon, showing a good separation of OC from EC. This amount of $\mathrm{C}_{\mathrm{ex}}$ was identical to that applied to the pure reference materials above, further corroborating the constant background introduced by the ECT9 protocol and ${ }^{14} \mathrm{C}$ analysis.

Next, the mixtures of fossil adipic acid (pure OC) and modern rice char (mixture of OC and EC) were isolated and analyzed. It was found that after correction for $\mathrm{C}_{\mathrm{ex}}$, the $\mathrm{F}^{14} \mathrm{C}$ values of the $\mathrm{OC}$ (from the mixture) were systematically greater than the consensus value of the pure adipic acid, i.e., a $\mathrm{F}^{14} \mathrm{C}$ of zero (Fig. 5a), indicating that there was certain level of modern fraction contributed to the measured OC from the modern rice char. Based on an elevated mean value of $0.1081 \pm 0.0259(n=6)$ after blank corrections, a mass balance calculation indicates that $10 \pm 3 \%$ of rice char OC is present. The high end of this estimation is close to $\sim 14 \%$, within a validity range of what one would expect.

To confirm that ECT9 could remove OC contained in rice char, an additional step was taken before mixing modern rice char's EC with the fossil OC (adipic acid). Specifically, we stripped the $\mathrm{OC}$ fraction of rice char by running rice char (on a filter) through the ECT9 protocol. Adipic acid (fossil OC) was then injected onto the filter with the remaining rice char EC. The results show that the $\mathrm{F}^{14} \mathrm{C}$ of $\mathrm{OC}$ values of this mixture lie well within the expected range of the consensus value (Fig. 5b) after a $\mathrm{C}_{\mathrm{ex}}$ correction as described above, demonstrating an excellent removal of rice char OC.

In both mixtures (fossil adipic acid with modern bulk rice char or rice char $\mathrm{EC})$, the corrected $\mathrm{F}^{14} \mathrm{C}$ values of the isolated EC fractions were within the expected range for the rice char reference material (Fig. $5 \mathrm{c}$ and d). This provides further evidence that the ECT9 protocol isolates modern EC from fossil OC with no obvious evidence of transferring fossil OC into the EC fraction. Together, the three sets of mixing experiments (Figs. 4 and 5) provide strong evidence for the effectiveness of separating OC from EC via ECT9 protocol.

In addition to $\mathrm{F}^{14} \mathrm{C}$ measurements, $\delta^{13} \mathrm{C}$ measurements in mixtures of $\mathrm{OC}$ and $\mathrm{EC}$ can also provide quantitative information on the effectiveness of $\mathrm{OC}$ and $\mathrm{EC}$ separation via ECT9. Various amounts of sucrose (pure OC, 10-30 $\mu \mathrm{g} \mathrm{C}$ ) were first mixed with varying amounts of regal black (pure 

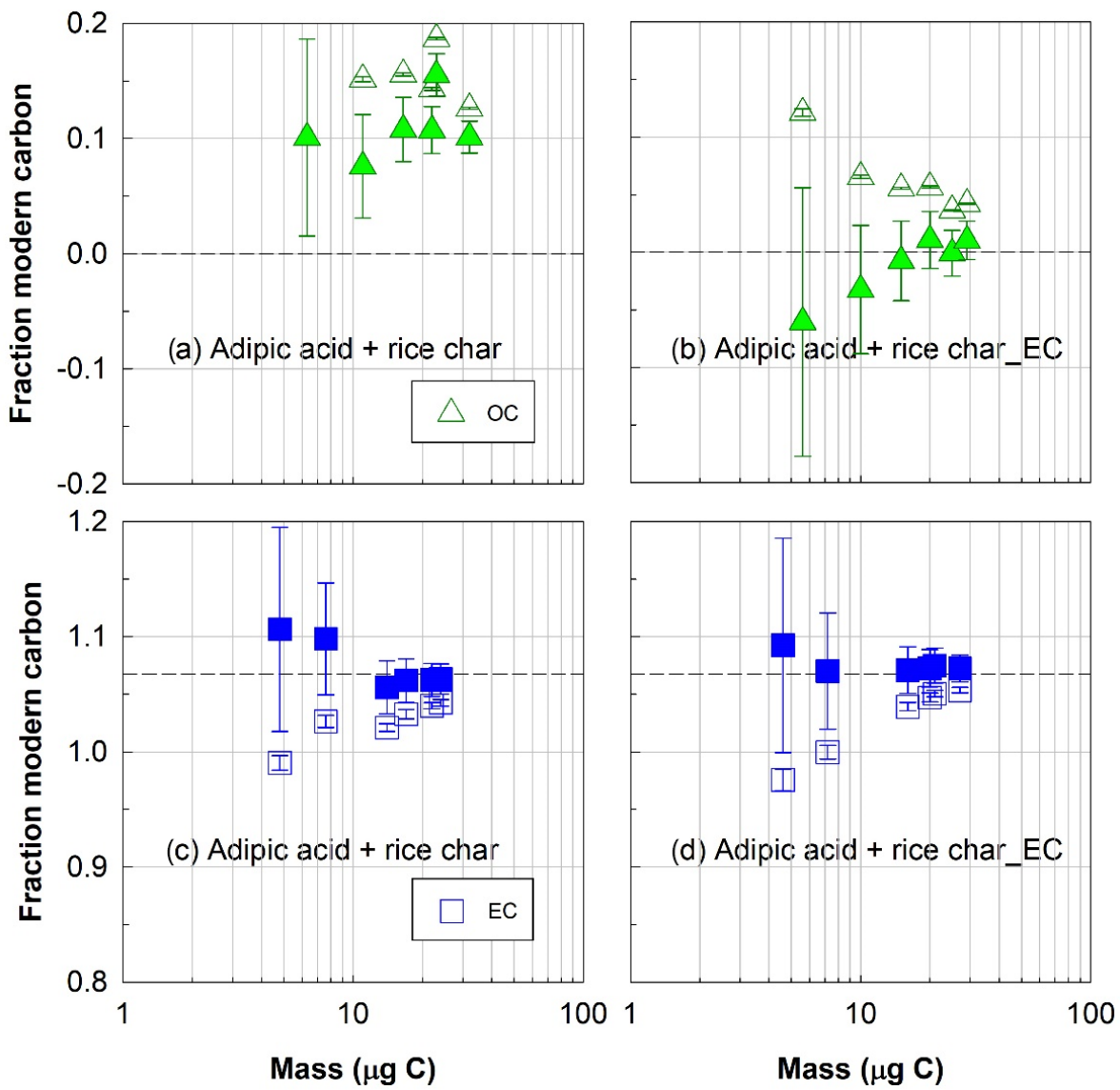

Figure 5. Radiocarbon $\left({ }^{14} \mathrm{C}\right)$ compositions, expressed in fraction modern carbon, of organic (OC, triangles) and elemental (EC, squares) carbon fractions isolated with the ECT9 protocol from the mixtures of reference materials. Fraction of modern carbon (a) OC and (c) EC isolated from mixtures of pure fossil OC (adipic acid) with modern bulk rice char (made of $14 \%$ OC and $86 \%$ EC) and of (b) OC and (d) EC isolated from mixtures of pure fossil OC (adipic acid) with modern EC from rice char_EC (rice char_OC has been removed before mixing). Open and solid symbols represent data before and after correction for extraneous carbon introduced during OC/EC isolation via ECT9 and subsequent ${ }^{14} \mathrm{C}$ analysis via AMS, respectively (Table S7). The dashed line indicates the consensus value (see Table 2).

EC, 20-66 $\mu \mathrm{g} \mathrm{C).} \mathrm{The} \mathrm{mixtures} \mathrm{were} \mathrm{then} \mathrm{physically} \mathrm{sepa-}$ rated into OC and $\mathrm{EC}$ fractions by ECT9 for $\delta^{13} \mathrm{C}$ measurements. The measured $\delta^{13} \mathrm{C}$ values of $\mathrm{OC}$ and $\mathrm{EC}$ from these mixing experiments are listed in Table S4. Based on the $\delta^{13} \mathrm{C}$ values of individual pure reference materials (Table S3) and a two end-member mixing mass balance, it is estimated that the average fraction contributed into each other in the mixtures (i.e., sucrose fraction into regal black or vice versa) was likely less than $3 \%$ (Table S5).

\subsection{Charring evaluation and PyOC removal using the ECT9 protocol}

It is known that some of OC (e.g., oxygenated OC or watersoluble OC) would char to form pyrolyzed organic carbon (PyOC) when heated in an inert He atmosphere, darkening the filter (Chow et al., 2004; Watson et al., 2007) and causing decreased laser signals due to light absorption of charred OC. In most TOA protocols, this PyOC would combust and contribute to EC when $\mathrm{O}_{2}$ is added. However, PyOC can be also be gasified and released as $\mathrm{CO}$ at high temperatures $\left(>700^{\circ} \mathrm{C}\right)$ with limited $\mathrm{O}_{2}$ supply, e.g., oxygenated $\mathrm{OC}$ at $870^{\circ} \mathrm{C}$ (Huang et al., 2006; Chan et al., 2010, 2019). Most TOA protocols estimate PyOC by quantifying the mass associated with reflectance and transmittance changes, i.e., the mass released between the time when $\mathrm{O}_{2}$ is introduced and the OC/EC split point (where the reflectance and transmittance returns to the initial value). In contrast to other TOA protocols, ECT9 defines PyOC as the mass released at the temperature step of $870^{\circ} \mathrm{C}$ (during a period of $600 \mathrm{~s}$ ). This includes charred $\mathrm{OC}$, calcium carbonate $\left(\mathrm{CaCO}_{3}\right)$ that decomposes at $830^{\circ} \mathrm{C}$, and any refractory $\mathrm{OC}$ not thermally released at $550^{\circ} \mathrm{C}$ (Huang et al., 2006; Chan et al., 2010, 2019).

Although ECT9 does not use laser signals to quantify PyOC, it is expected that the changes of laser signals during the stage of $870^{\circ} \mathrm{C}$ would provide useful information about PyOC. Thus, four sets of samples were selected, including 
(a)

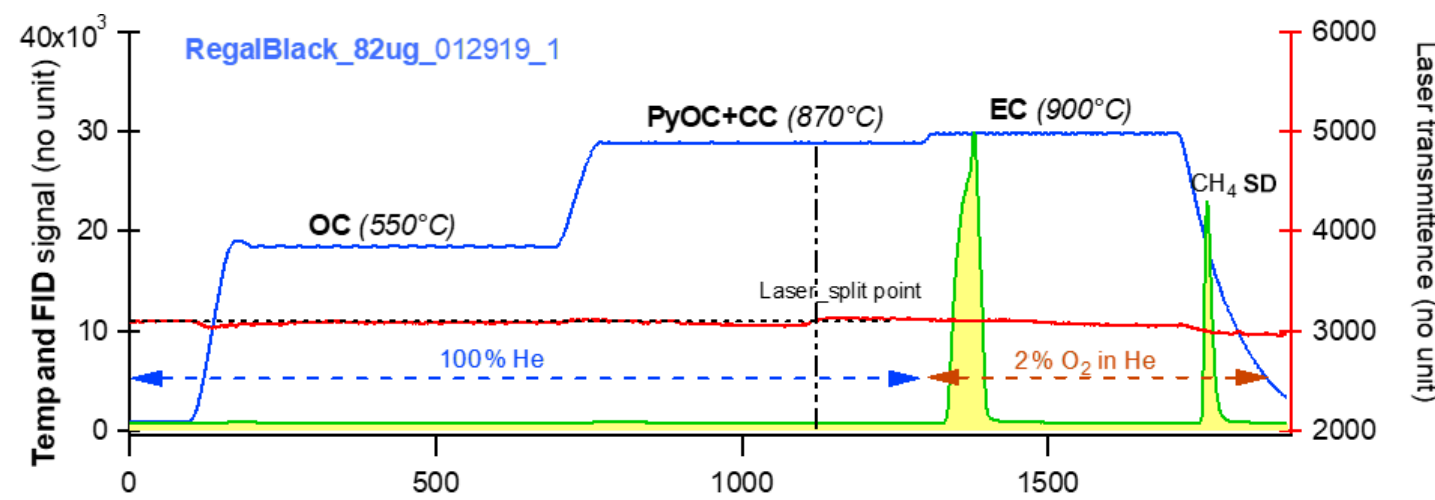

(b)

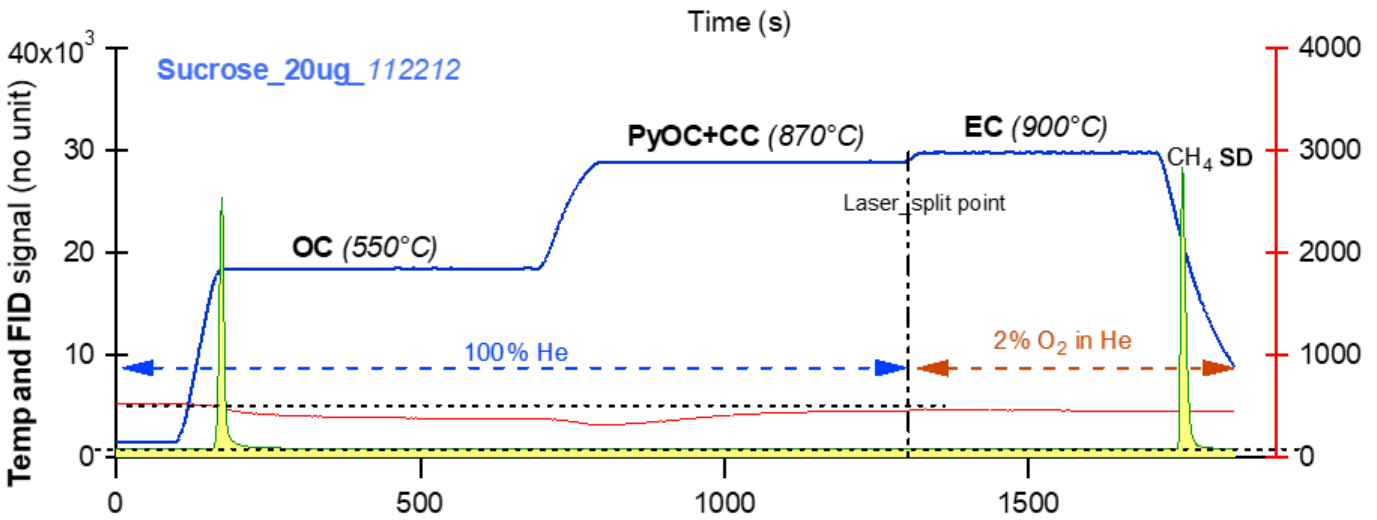

(c)

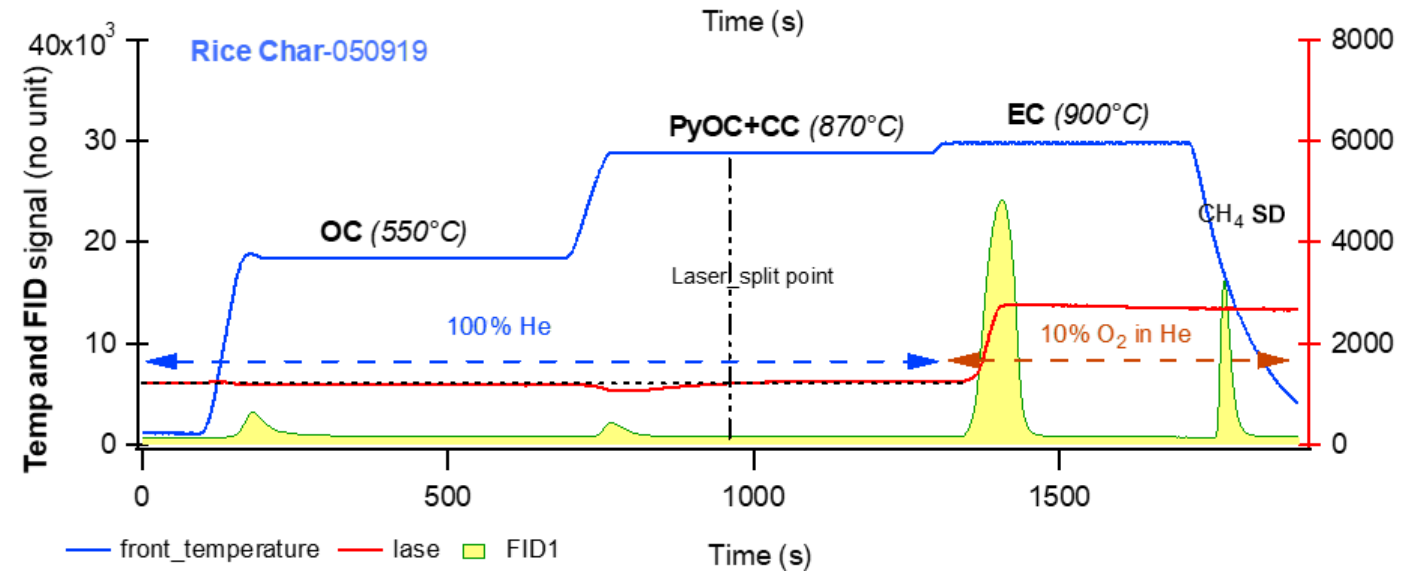

Figure 6. Thermograms of pure or bulk references: (a) regal black, (b) sucrose, and (c) rice char. Temperature (solid blue line) and FID signals (integrated yellow area with green line) on the left axes and laser (solid red line) on the right axis. It is observed that on the three thermograms during the temperature stage of $870^{\circ} \mathrm{C}$, the laser transmittance signals decrease first and increase again before the next temperature stage, minimizing PyOC fraction, i.e., possible charred OC contribution to EC.

those of pure reference materials and ambient aerosol samples from different sources with heavy or light mass loading (e.g., those arctic sample filters from different seasons) to evaluate the possible charring via ECT9. Their thermograms are shown in Figs. 6 to 9.

Figure $6 \mathrm{a}-\mathrm{c}$ show thermograms of pure or bulk references for regal black, sucrose, and rice char, respectively. It is observed in all three panels that the laser transmittance signals first decrease and then increase again during the $870^{\circ} \mathrm{C}$ step and that they return to their initial values just before $\mathrm{EC}$ is released at the next step of $900^{\circ} \mathrm{C}$. This demonstrates that the ECT9 method minimizes PyOC contributions to the EC fraction.

The thermograms of aerosol (on filters) collected directly from tailpipe exhaust of a diesel engine vehicle and a gasoline engine passage car, respectively are shown in Fig. 7. These data suggest that the amount of PyOC generated during analysis are sample/matrix dependent. Specifically, the 
(a)

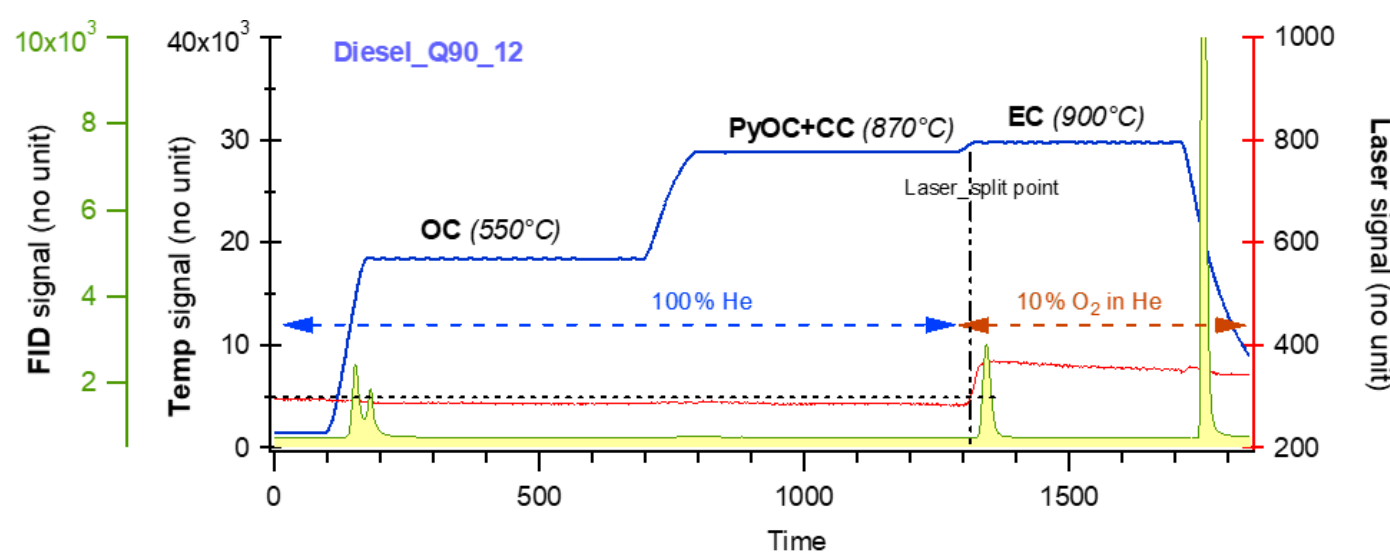

(b)

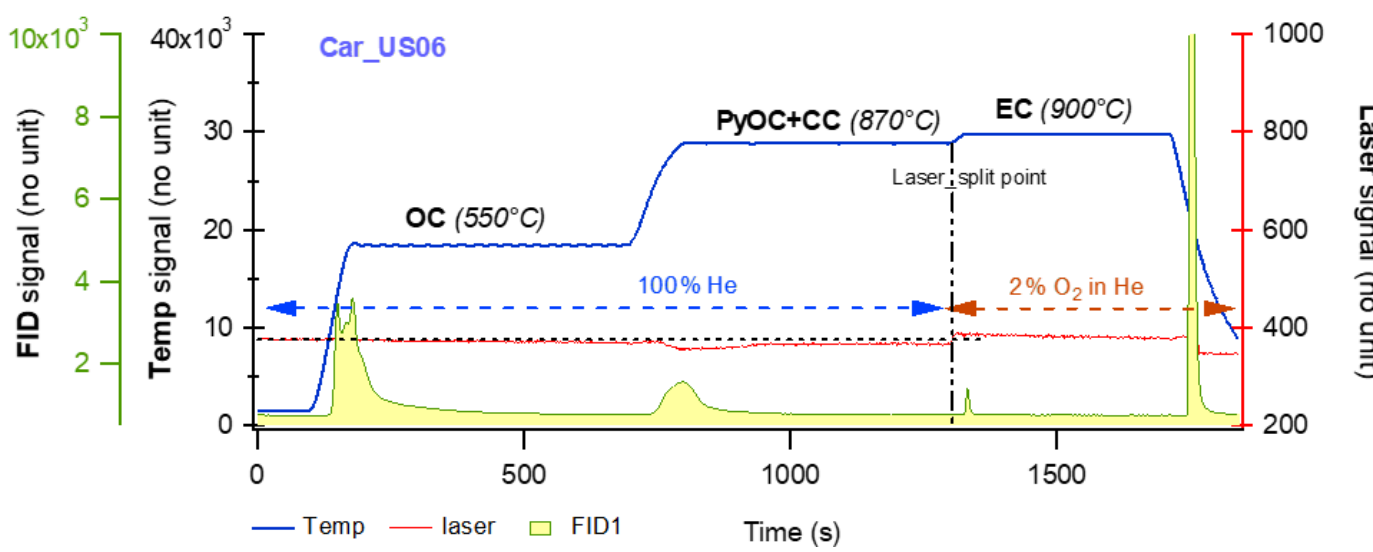

Figure 7. Thermograms of the filters directly collected from tailpipe exhaust of a diesel engine vehicle in (a) and a gasoline engine passage car in (b). The legends are the same as Fig. 6. Note that the mass fraction from the temperature stage of $870^{\circ} \mathrm{C}$ in (b) is obviously larger than that in (a). The latter is negligible, indicating that the amount of PyOC fraction is sample matrix dependent. The amount of PyOC from gasoline vehicle emissions is likely larger than that from diesel vehicle emissions. Note that the laser signal reaches the initial value before the $900^{\circ} \mathrm{C}$ stage for EC releasing, demonstrating that the charring contribution to EC is minimized.

mass fraction during the $870^{\circ} \mathrm{C}$ temperature is larger for the gasoline than the diesel engine. This finding supports previous work showing that PyOC is proportional to the amount of oxygenated OC (Chan et al., 2010). It is noticed that the laser signal reaches the initial value before the EC step, further demonstrating that the charring contribution to EC is minimized.

Another set of thermograms of two total suspended particle filter samples collected during the summer (August) and winter (December) of 2015 at an arctic site (i.e., Alert) are shown in Fig. 8. More details about these samples can be found in Wex et al. (2019). The laser signal patterns are similar to those shown in Figs. 6 and 7, yet more pronounced. During the $550^{\circ} \mathrm{C}$ step, the laser signals decrease. During the $870^{\circ} \mathrm{C}$ step, the signals further decrease, then increase, and finally increase to their initial point before EC is released at $900^{\circ} \mathrm{C}$. These thermograms further demonstrate ECT9 is able to minimize PyOC by gasification.

Finally, the thermographs of NIST urban dust reference material SRM 8785 (the resuspended SRM 1649a urban dust with a fine fraction $<2.5 \mu \mathrm{m}$ collected on quartz filter) analyzed with ECT9 and Swiss_4S are shown in Fig. 9. Both thermograms obtained with the ECT9 method (Fig. 9a and b) show the similar patterns as those in Figs. 6-8, i.e., the laser signals reaching the initial value just before the EC release at $900{ }^{\circ} \mathrm{C}$, suggesting that the charring contribution to EC is minimized during the stage of $870^{\circ} \mathrm{C}$ even though some PyOC might remain.

In the thermogram obtained with the Swiss-4S protocol (Fig. 9c), the laser signal increases from the beginning of the run while the first two stages $\left(375\right.$ and $475^{\circ} \mathrm{C}$ ) are under the conditions of pure $\mathrm{O}_{2}$ stream, inferring that light absorbing carbon is released during the first two OC stages. The laser signal continues to increase while the temperature increases up to $650{ }^{\circ} \mathrm{C}$ (the third stage) under the pure He gas stream, indicating that no charred $\mathrm{OC}$ is formed. However, when the temperature starts decreasing from $650^{\circ} \mathrm{C}$, the laser signal decreases, indicating PyOC formation below that temperature. This signal decrease continues until the beginning of the next pure $\mathrm{O}_{2}$ stage. It is important to note that to ob- 


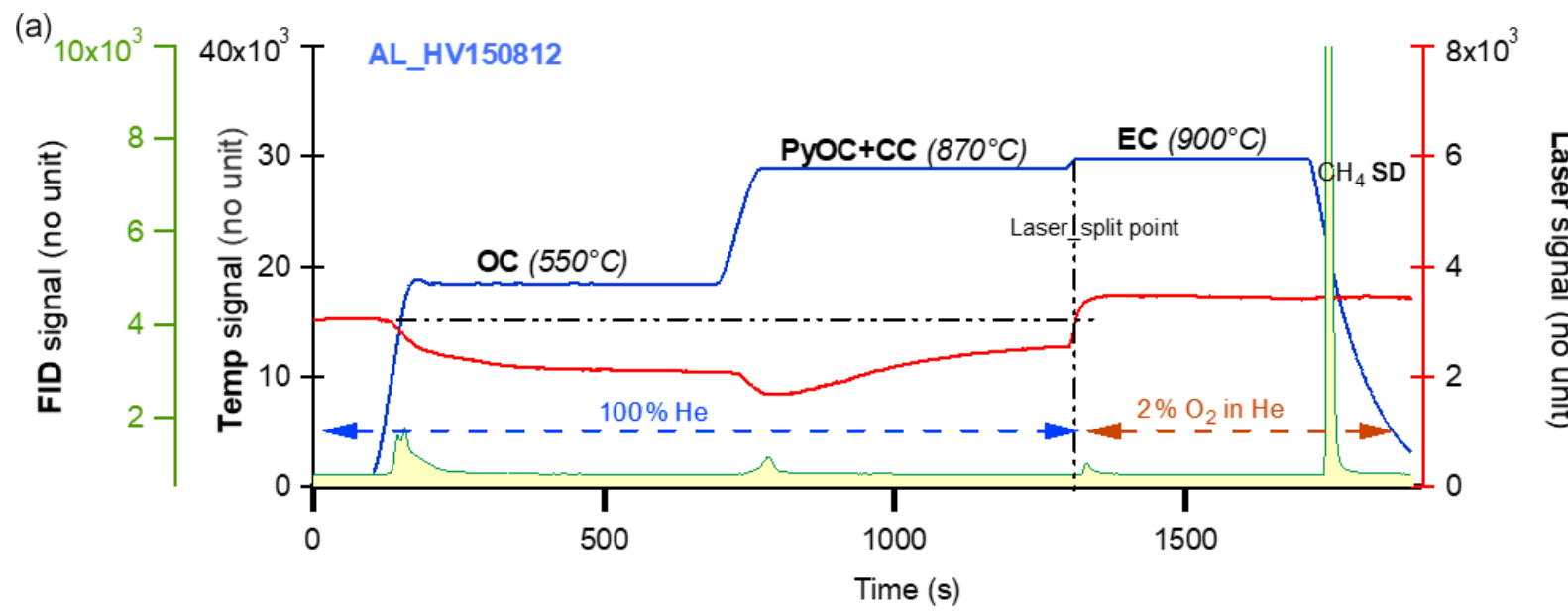

(b)

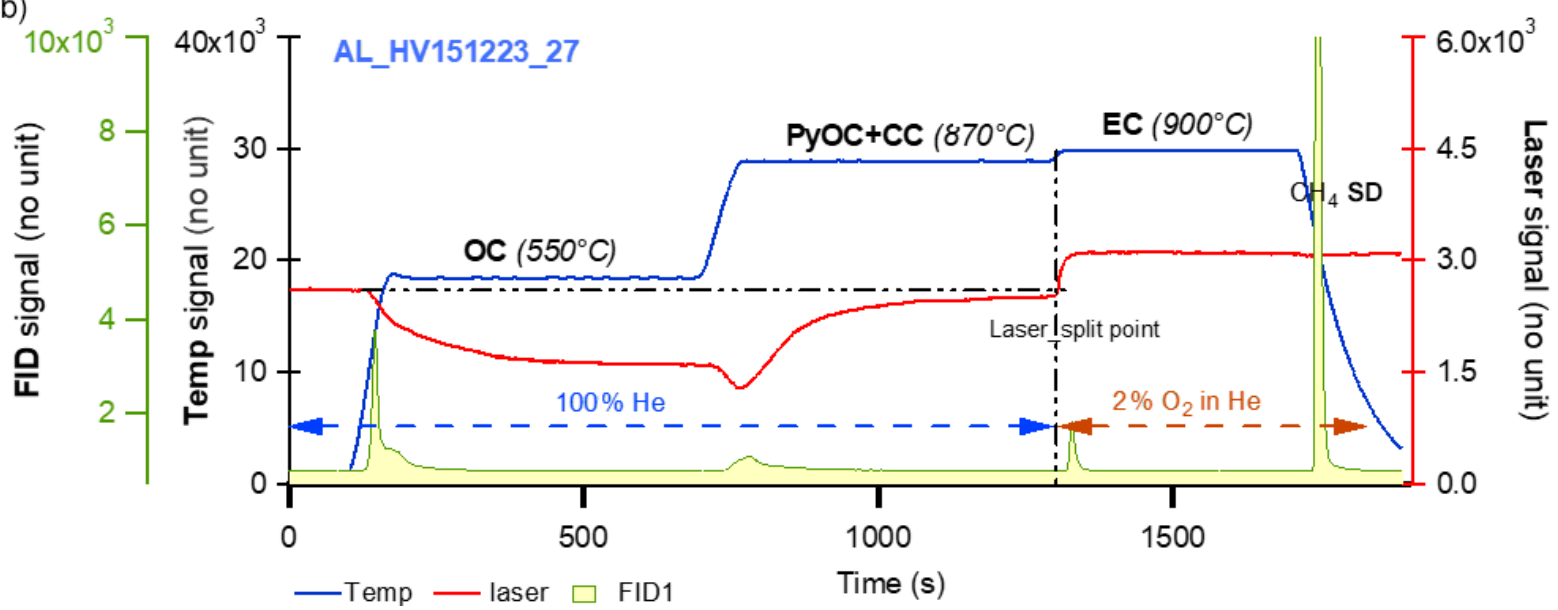

Figure 8. Thermograms of fine particles $\left(\mathrm{PM}_{1.0} \mu \mathrm{m}\right)$ from the filter samples collected at an arctic site, i.e., Alert, NU, Canada, in summer (a) and winter (b) 2015. The legends are the same as Fig. 6. It is clearly shown on both thermograms that during $550{ }^{\circ} \mathrm{C}$ stage, the laser signal starts decreasing (implying charred OC formation) and begins increasing at $870^{\circ} \mathrm{C}$ and reaches the initial value before the EC stage (indicating the contribution to EC by charred OC is minimized or removed).

tain EC fraction, the Swiss-4 (Table 3) method calls for filter sample pre-treatment, i.e., extraction with water before the thermal separation of OC/EC to minimize the contribution of charred $\mathrm{OC}$ from the 3rd stage to EC at the 4th stage (Zhang et al., 2012). However, for a method comparison, the thermogram shown in Fig. 9c was from a filter without pretreatment. While it is difficult to make direct comparisons between OC and EC from Fig. 9a and c, the laser profiles from those thermograms in Fig. 9a and b indicate that in both cases charred OC is negligible or minimum via ECT9.

Together, the thermograms (Figs. 6-9) elucidate that the ECT9 protocol can effectively remove or minimize charred OC (PyOC) to achieve good physical separation of OC and EC. Another great advantage of using ECT9 to separate OC from EC for isotope analysis (both ${ }^{13} \mathrm{C}$ and ${ }^{14} \mathrm{C}$ ) is its consistency with the protocol used for $\mathrm{OC}$ and $\mathrm{EC}$ concentration measurements. Moreover, the ECT9 method does not require filter samples to be pre-extracted with water before EC analysis (to reduce PyOC).

\section{Conclusions}

We demonstrate the effectiveness of the ECT9 protocol to physically isolate OC and EC from aerosol samples for ${ }^{14} \mathrm{C}$ and ${ }^{13} \mathrm{C}$ analysis by using $\mathrm{OC}$ and $\mathrm{EC}$ reference materials on their own and as mixtures. It was found that the ECT9 protocol successfully separates OC and EC fractions with a low (but largely modern) total carbon blank of $1.3 \pm 0.6 \mu \mathrm{g} \mathrm{C}$. The majority $(65 \%)$ of this extraneous carbon originates from the isolation with the ECT9 protocol, with $35 \%$ contributed from graphitization and ${ }^{14} \mathrm{C}$ measurement of the samples at the KCCAMS facility. After mass balance background corrections, the $\mathrm{F}^{14} \mathrm{C}$ results from both bulk pure materials and mixtures (with sample size as small as $5 \mu \mathrm{g} \mathrm{C}$ ) can 
(a)

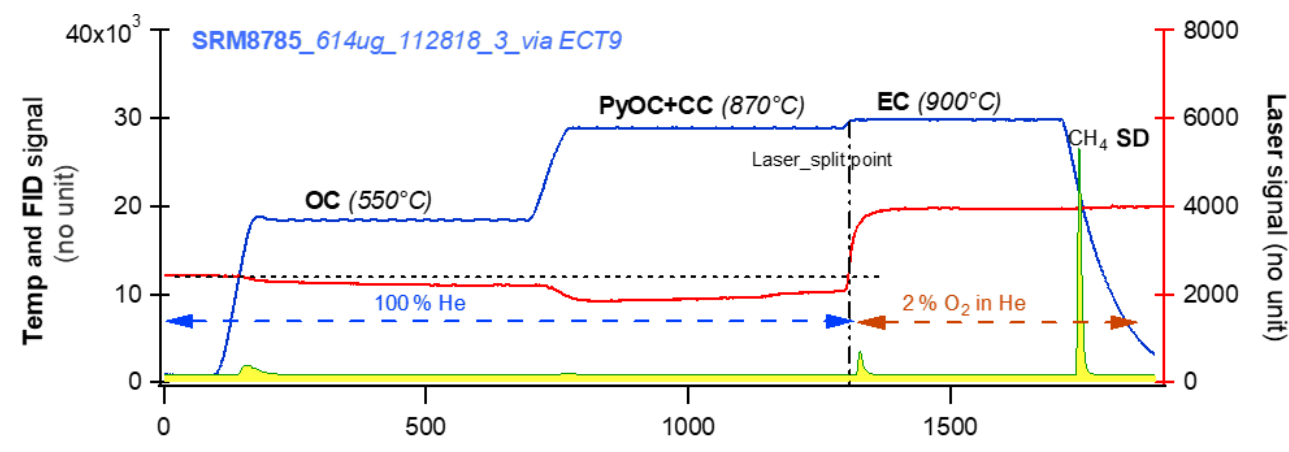

(b)

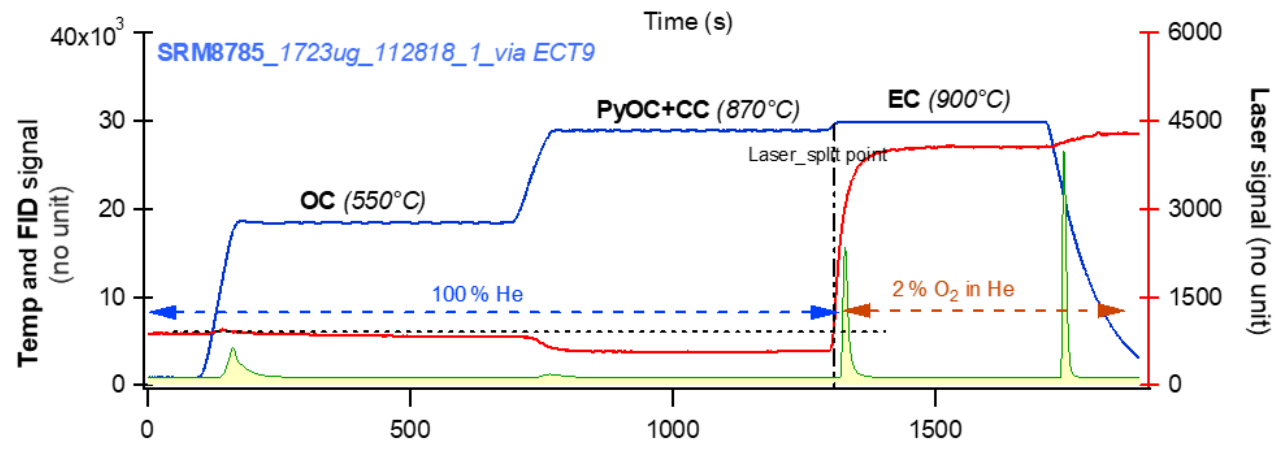

(c)

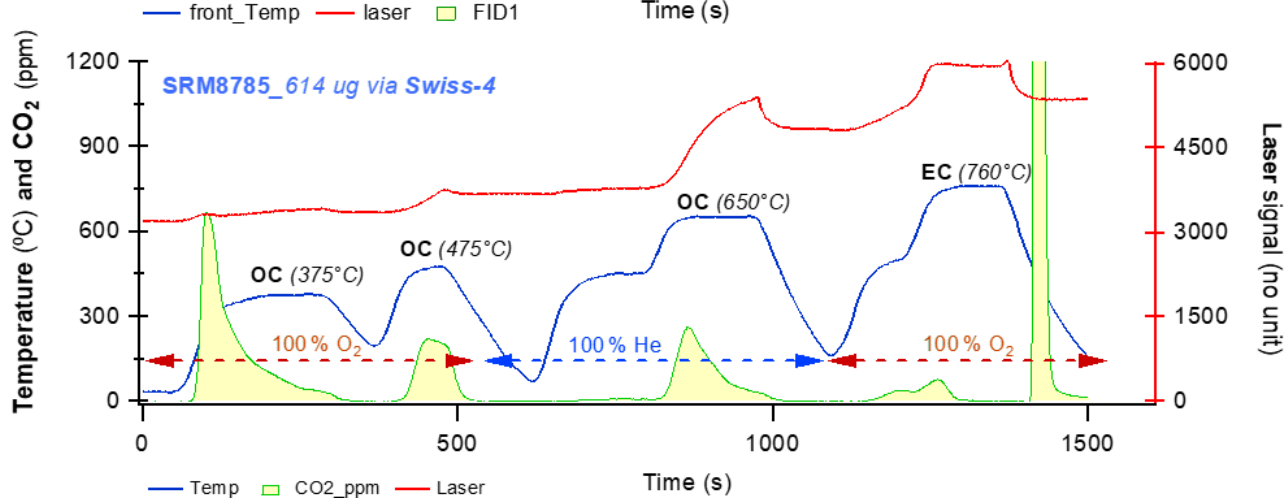

Figure 9. Thermograms of the SRM 8785 filters (the fine fraction $\left(\mathrm{PM}_{2.5}\right)$ of resuspended urban dust particles from SRM 1649a and collected on quartz filters) with various amount of materials ranging from 614 to $1723 \mathrm{mg}$ via two different thermal protocols. Panels (a) and (b) were obtained by ECT9. The legends are the same as Fig. 6. Thermograms in (a) and (b) show the similar patterns as in Figs. 6-8 that the laser signals reaching the initial value are just before the temperature stage of EC, suggesting that the charred OC contribution to EC is minimized. The thermogram in (c) is obtained from the same filter in (b) but by Swiss-4 protocol for comparison. The legends are similar except for the integrated area with green line, which stands for $\mathrm{CO}_{2}$ in parts per million (by non-dispersive infrared) instead of FID signals.

reach the consensus values (Table 2) with an average uncertainty of about $5 \%$.

In addition, we evaluated potential PyOC formation during ECT9 by investigating thermograms of a variety of reference materials and ambient filter samples. It is demonstrated that ECT9 provides a good alternative for carbonaceous aerosol source apportionment studies, including ultra small sized (5$15 \mu \mathrm{g} \mathrm{C})$ samples obtained from arctic regions. To increase the application of isotope data $\left({ }^{14} \mathrm{C}\right.$ or $\left.{ }^{13} \mathrm{C}\right)$ in atmospheric research, future efforts should be focused on the comparison on OC/EC separation via different methods/protocols using the same sets of reference materials. At the same time, the isolation results should be also compared among those meth- ods/protocols widely used in long-term national monitoring network for OC/EC contents, ensuring a consistency in measurements between OC/EC concentrations and their corresponding isotopic compositions. 


\section{Appendix A: Nomenclature}

\begin{tabular}{ll} 
AMS & Accelerator Mass Spectrometry \\
ASTD & Atmospheric Science and Technology Directorate \\
BC & Black carbon \\
CABM & Canadian Aerosol Baseline Measurement \\
CAIR & Carbonaceous Aerosol and Isotope Research \\
CCMR & Climate Chemistry Measurements and Research \\
CC & Carbonate carbon \\
CRD & Climate Research Division \\
EC & Elemental carbon \\
ECCC & Environment and Climate Change Canada \\
ECT9 & EnCan-Total-900 protocol \\
EUSAAR & European Supersites for Atmospheric Aerosol Research \\
FID & Flame ionization detector \\
F ${ }^{14}$ C & Fraction Modern Carbon \\
ICP & Inter-comparison study \\
IRMS & Isotopic Ratio Mass Spectrometer \\
IMPROVE & Interagency Monitoring PROtected Visual Environments \\
KCCAMS & W.M. Keck Carbon Cycle Accelerator Mass Spectrometry Facility \\
MAC & Mass absorption coefficient \\
NIST & National Institute of Standard and Technology \\
OC & Organic carbon \\
PM & Particulate matter \\
PyOC & Pyrolyzed organic carbon \\
PSAP & Particle Soot Absorption Photometer \\
rBC & Refractory Black Carbon \\
SP2 & Single Particle Soot Photometer \\
SRM & Standard Reference Material \\
TC & Total carbon \\
TEA & Thermal evolution analysis \\
TOA & Thermal optical analysis \\
UCI & University of California, Irvine \\
& \\
\hline
\end{tabular}


Data availability. All data presented in this article are included in the supplement.

Supplement. The supplement related to this article is available online at: https://doi.org/10.5194/amt-14-3481-2021-supplement.

Author contributions. Conceptualizing and designing the study: LH, CIC, and GMS. Developing analytical methods and ensuring data quality: LH, GMS, WZ, CIC, BTR. Performing the experiments and data acquisition: WZ, GMS, SRH, VV, BTR. Data organizing/analysis and interpretation: LH, CIC, BTR, GMS, WZ. Writing the paper, including editing and preparing figures and tables: LH, CIC, BTR, GMS, WZ.

Competing interests. The authors declare that they have no conflict of interest.

Acknowledgements. This research was supported by A-base funding from Environment and Climate Change Canada and the $\mathrm{KC}$ CAMS Facility at the University of California, Irvine through G.M.S. We thank Darrell Enrst (ECCC) and John Southon (KCCAMS) for supporting ${ }^{13} \mathrm{C}$ IRMS and ${ }^{14} \mathrm{C}$ AMS analyses, respectively.

Review statement. This paper was edited by Pierre Herckes and reviewed by three anonymous referees.

\section{References}

Andersson, A., Deng, J., Du, K., Zheng, M., Yan, C., Sköld, M., and Gustafsson, Ö.: Regionally-Varying Combustion Sources of the January 2013 Severe Haze Events over Eastern China, Environ. Sci. Technol., 49, 2038-2043, https://doi.org/10.1021/es503855e, 2015.

Barrett, T. E., Robinson, E. M., Usenko, S., and Sheesley, R. J.: Source Contributions to Wintertime Elemental and Organic Carbon in the Western Arctic Based on Radiocarbon and Tracer Apportionment, Environ. Sci. Technol., 49, 11631-11639, https://doi.org/10.1021/acs.est.5b03081, 2015.

Beverly, R. K., Beaumont, W., Tauz, D., Ormsby, K. M., Von Reden, K. F., Santos, G. M., and Southon, J. R.: The Keck Carbon Cycle AMS laboraoty, University of California, Irvine Status report, Radiocarbon, 52, 301-309, 2010.

Birch, M. E.: Applied Occupational and Environmental Hygiene Occupational Monitoring of Particulate Diesel Exhaust by NIOSH Method 5040, Applied Occupational and Environmental Hygiene, 17, 400-405, https://doi.org/10.1080/10473220290035390, 2002.

Bond, T. C., Doherty, S. J., Fahey, D. W., Forster, P. M., Berntsen, T., DeAngelo, B. J., Flanner, M. G., Ghan, S., Kärcher, B., Koch, D., Kinne, S., Kondo, Y., Quinn, P. K., Sarofim, M. C., Schultz, M. G., Schulz, M., Venkataraman, C., Zhang, H., Zhang, S., Bel- louin, N., Guttikunda, S. K., Hopke, P. K., Jacobson, M. Z., Kaiser, J. W., Klimont, Z., Lohmann, U., Schwarz, J. P., Shindell, D., Storelvmo, T., Warren, S. G., and Zender, C. S.: Bounding the role of black carbon in the climate system: A scientific assessment, J. Geophys. Res.-Atmos., 118, 5380-5552, 2013.

Cavalli, F., Viana, M., Yttri, K. E., Genberg, J., and Putaud, J.-P.: Toward a standardised thermal-optical protocol for measuring atmospheric organic and elemental carbon: the EUSAAR protocol, Atmos. Meas. Tech., 3, 79-89, https://doi.org/10.5194/amt-3-792010, 2010.

Chan, T. W., Huang, L., Leaitch, W. R., Sharma, S., Brook, J. R., Slowik, J. G., Abbatt, J. P. D., Brickell, P. C., Liggio, J., Li, S.M., and Moosmüller, H.: Observations of OM/OC and specific attenuation coefficients (SAC) in ambient fine PM at a rural site in central Ontario, Canada, Atmos. Chem. Phys., 10, 2393-2411, https://doi.org/10.5194/acp-10-2393-2010, 2010.

Chan, T. W., Meloche, E., Kubsh, J., Brezny, R., Rosenblatt, D., and Rideout, G.: Impact of Ambient Temperature on Gaseous and Particle Emissions from a Direct Injection Gasoline Vehicle and its Implications on Particle Filtration, SAE International Journal of Fuels and Lubricants, 6, 350-371, https://doi.org/10.4271/2013-01-0527, 2013.

Chan, T. W., Huang, L., Banwait, K., Zhang, W., Ernst, D., Wang, X., Watson, J. G., Chow, J. C., Green, M., Czimczik, C. I., Santos, G. M., Sharma, S., and Jones, K.: Intercomparison of elemental and organic carbon mass measurements from three North American national long-term monitoring networks at a co-located site, Atmos. Meas. Tech., 12, 4543-4560, https://doi.org/10.5194/amt-12-4543-2019, 2019.

Chow, J. C., Watson, J. G., Crow, D., Lowenthal, D. H., and Merrifield, T.: Comparison of IMPROVE and NIOSH Carbon Measurements, Aerosol Sci. Technol., 34, 23-34, 2001.

Chow, J. C., Watson, J. G., Chen, L. W. A., Arnott, W. P., Moosmüller, H., and Fung, K.: Equivalence of elemental carbon by thermal/optical reflectance and transmittance with different temperature protocols, Environ. Sci. Technol., 38, 4414-4422, https://doi.org/10.1021/es034936u, 2004.

Cohen, A. J., Brauer, M., Burnett, R., Anderson, H. R., Frostad, J., Estep, K., Balakrishnan, K., Brunekreef, B., Dandona, L., Dandona, R., Feigin, V., Freedman, G., Hubbell, B., Jobling, A., Kan, H., Knibbs, L., Liu, Y., Martin, R., Morawska, L., Pope, C. A., Shin, H., Straif, K., Shaddick, G., Thomas, M., van Dingenen, R., van Donkelaar, A., Vos, T., Murray, C. J. L., and Forouzanfar, M. H.: Estimates and 25-year trends of the global burden of disease attributable to ambient air pollution: an analysis of data from the Global Burden of Diseases Study 2015, Lancet, 389, 1907-1918, https://doi.org/10.1016/S0140-6736(17)30505-6, 2017.

Currie, L. A., Benner, B. A. J., Kessler, J. D., Klinedinst, D. B., Klouda, G. A., Marolf, J. V., Slater, J. F., Wise, S. A., Cachier, H., Cary, R., Chow, J. C., Watson, J., Druffel, E. R. M., Masiello, C. A., Eglinton, T. I., Pearson, A., Reddy, C. M., Gustafsson, Ö., Quinn, J. G., Hartmann, P. C., Hedges, J. I., Prentice, K. M., Kirchstetter, T. W., Novakow, T., Puxbaum, H., and Schmid, H.: A Critical Evaluation of Interlaboratory Data on Total, Elemental, and Isotopic Carbon in the Carbonaceous Particle Reference Material, NIST SRM 1649a, J. Res. Natl. Inst. Stan., 107, 279 298, 2002.

Eckhardt, S., Quennehen, B., Olivié, D. J. L., Berntsen, T. K., Cherian, R., Christensen, J. H., Collins, W., Crepinsek, S., 
Daskalakis, N., Flanner, M., Herber, A., Heyes, C., Hodnebrog, Ø., Huang, L., Kanakidou, M., Klimont, Z., Langner, J., Law, K. S., Lund, M. T., Mahmood, R., Massling, A., Myriokefalitakis, S., Nielsen, I. E., Nøjgaard, J. K., Quaas, J., Quinn, P. K., Raut, J.-C., Rumbold, S. T., Schulz, M., Sharma, S., Skeie, R. B., Skov, H., Uttal, T., von Salzen, K., and Stohl, A.: Current model capabilities for simulating black carbon and sulfate concentrations in the Arctic atmosphere: a multi-model evaluation using a comprehensive measurement data set, Atmos. Chem. Phys., 15, 9413-9433, https://doi.org/10.5194/acp-15-9413-2015, 2015.

Evangeliou, N., Balkanski, Y., Hao, W. M., Petkov, A., Silverstein, R. P., Corley, R., Nordgren, B. L., Urbanski, S. P., Eckhardt, S., Stohl, A., Tunved, P., Crepinsek, S., Jefferson, A., Sharma, S., Nøjgaard, J. K., and Skov, H.: Wildfires in northern Eurasia affect the budget of black carbon in the Arctic - a 12-year retrospective synopsis (2002-2013), Atmos. Chem. Phys., 16, 75877604, https://doi.org/10.5194/acp-16-7587-2016, 2016.

Fuzzi, S., Baltensperger, U., Carslaw, K., Decesari, S., Denier van der Gon, H., Facchini, M. C., Fowler, D., Koren, I., Langford, B., Lohmann, U., Nemitz, E., Pandis, S., Riipinen, I., Rudich, Y., Schaap, M., Slowik, J. G., Spracklen, D. V., Vignati, E., Wild, M., Williams, M., and Gilardoni, S.: Particulate matter, air quality and climate: lessons learned and future needs, Atmos. Chem. Phys., 15, 8217-8299, https://doi.org/10.5194/acp15-8217-2015, 2015.

Grahame, T. J., Klemm, R., Schlesinger, R. B., Gwen Eklund, A., Chow, J. C., Greenbaum, D. S., Hidy, G. M., Kleinman, M. T., Watson, J. G., Wyzga, R. E., Grahame, T. J., Klemm, R., and Schlesinger, R. B.: Public health and components of particulate matter: The changing assessment of black carbon, J. Air Waste Manage., 64, 1221-1231, https://doi.org/10.1080/10962247.2014.960218, 2014.

Graven, H., Keeling, R. F., and Rogelj, J.: Changes to Carbon Isotopes in Atmospheric $\mathrm{CO}_{2}$ over the Industrial Era and into the Future, Global Biogeochem. Cy., 34, e2019GB006170, https://doi.org/10.1029/2019GB006170, 2020.

Graven, H. D.: Impact of fossil fuel emissions on atmospheric radiocarbon and various applications of radiocarbon over this century, P. Natl. Acad. Sci. USA, 112, 9542-9545, https://doi.org/10.1073/pnas.1504467112, 2015.

Hallquist, M., Wenger, J. C., Baltensperger, U., Rudich, Y., Simpson, D., Claeys, M., Dommen, J., Donahue, N. M., George, C., Goldstein, A. H., Hamilton, J. F., Herrmann, H., Hoffmann, T., Iinuma, Y., Jang, M., Jenkin, M. E., Jimenez, J. L., Kiendler-Scharr, A., Maenhaut, W., McFiggans, G., Mentel, Th. F., Monod, A., Prévôt, A. S. H., Seinfeld, J. H., Surratt, J. D., Szmigielski, R., and Wildt, J.: The formation, properties and impact of secondary organic aerosol: current and emerging issues, Atmos. Chem. Phys., 9, 5155-5236, https://doi.org/10.5194/acp9-5155-2009, 2009.

Hand, J. L., Schichtel, B. A., Malm, W. C., and Frank, N. H.: Spatial and Temporal Trends in $\mathrm{PM}_{2.5}$ Organic and Elemental Carbon across the United States, Adv. Meteorol., 2013, 367674, https://doi.org/10.1155/2013/367674, 2013.

Hammes, K., Smernik, R. J., Skjemstad, J. O., Herzog, A., Vogt, U. F., and Schmidt, M. W. I.: Synthesis and characterisation of laboratory-charred grass straw (Oryza sativa) and chestnut wood (Castanea sativa) as reference materials for black carbon quantification, Org. Geochem., 37, 1629-1633, https://doi.org/10.1016/j.orggeochem.2006.07.003, 2006.

Hammes, K., Schmidt, M. W. I., Smernik, R. J., Currie, L. A., Ball, W. P., Nguyen, T. H., Louchouarn, P., Houel, S., Gustafsson, Ö., Elmquist, M., Cornelissen, G., Skjemstad, J. O., Masiello, C. A., Song, J., Peng, P., Mitra, S., Dunn, J. C., Hatcher, P.G., Hockaday, W. C., Smith, D. M., Hartkopf-Fröder, C., Böhmer, A., Lüer, B., Huebert, B. J., Amelung,W., Brodowski, S., Huang, L., Zhang, W., Gschwend, P. M., Flores-Cervantes, D. X., Largeau, C., Rouzaud, J-N., Rumpel, C., Guggenberger, G., Kaiser, K., Rodionov, A., Gonzalez-Vila, F.J., Gonzalez-Perez, J. A., de la Rosa, J. M., Manning, D. A. C., López-Capél, E., and Ding, L. Y.: Comparison of quantification methods to measure fire-derived (black/elemental) carbon in soils and sediments using reference materials from soil, water, sediment and the atmosphere, 21, GB3016, https://doi.org/10.1029/2006GB002914, 2007.

Heal, M. R.: The application of carbon-14 analyses to the source apportionment of atmospheric carbonaceous particulate matter: A review, Anal. Bioanal. Chem., 406, 81-98, https://doi.org/10.1007/s00216-013-7404-1, 2014.

Huang, L.: The issue of harmonizing the methodologies for emission inventories of GHGs with those of SLCFs, presentation at the IPCC Expert Meeting on SLCFs, Geneva, May 2018, available at: https://www.ipcc-nggip.iges.or.jp/public/mtdocs/1805_ Geneva.html (last access: 19 April 2021), 2018.

Huang, L., Brook, J. R., Zhang, W., Li, S. M., Graham, L., Ernst, D., Chivulescu, A., and Lu, G.: Stable isotope measurements of carbon fractions (OC/EC) in airborne particulate: A new dimension for source characterization and apportionment, Atmos. Environ., 40, 2690-2705, https://doi.org/10.1016/j.atmosenv.2005.11.062, 2006.

Huang, L., Gong, S. L., Sharma, S., Lavoué, D., and Jia, C. Q.: A trajectory analysis of atmospheric transport of black carbon aerosols to Canadian high Arctic in winter and spring (1990-2005), Atmos. Chem. Phys., 10, 5065-5073, https://doi.org/10.5194/acp-10-5065-2010, 2010.

Huang, L., Chivulescu, A., Ernst, D., Zhang, W., Norman, A.L., and Lee, Y.-S.: Maintaining consistent traceability in highprecision isotope measurements of $\mathrm{CO}_{2}$ : a way to verify atmospheric trends of $\delta^{13} \mathrm{C}$ and $\delta^{18} \mathrm{O}$, Atmos. Meas. Tech., 6, 16851705, https://doi.org/10.5194/amt-6-1685-2013, 2013.

Janssen, N. A., Gerlofs-Nijland, M. E., Lanki, T., Salonen, R. O., Cassee, F., Hoek, G., Fischer, P., Brunekreef, B., and Krzyzanowski, M.: Health effects of black carbon, WHO Regional Office for Europe, Copenhagen, Denmark, 2012.

Jimenez, J. L., Canagaratna, M. R., Donahue, N. M., Prevot, A. S. H., Zhang, Q., Kroll, J. H., DeCarlo, P. F., Allan, J. D., Coe, H., Ng, N. L., Aiken, A. C., Docherty, K. S., Ulbrich, I. M., Grieshop, A. P., Robinson, A. L., Duplissy, J., Smith, J. D., Wilson, K. R., Lanz, V. A., Hueglin, C., Sun, Y. L., Tian, J., Laaksonen, A., Raatikainen, T., Rautiainen, J., Vaattovaara, P., Ehn, M., Kulmala, M., Tomlinson, J. M., Collins, D. R., Cubison, M. J., Dunlea, E. J., Huffman, J. A., Onasch, T. B., Alfarra, M. R., Williams, P. I., Bower, K., Kondo, Y., Schneider, J., Drewnick, F., Borrmann, S., Weimer, S., Demerjian, K., Salcedo, D., Cottrell, L., Griffin, R., Takami, A., Miyoshi, T., Hatakeyama, S., Shimono, A., Sun, J. Y., Zhang, Y. M., Dzepina, K., Kimmel, J. R., Sueper, D., Jayne, J. T., Herndon, S. C., Trimborn, A. M., Williams, L. R., Wood, E. C., Middlebrook, A. M., 
Kolb, C. E., Baltensperger, U., and Worsnop, D. R.: Evolution of organic aerosols in the atmosphere, Science, 326, 1525-1529, https://doi.org/10.1126/science.1180353, 2009.

Kanakidou, M., Seinfeld, J. H., Pandis, S. N., Barnes, I., Dentener, F. J., Facchini, M. C., Van Dingenen, R., Ervens, B., Nenes, A., Nielsen, C. J., Swietlicki, E., Putaud, J. P., Balkanski, Y., Fuzzi, S., Horth, J., Moortgat, G. K., Winterhalter, R., Myhre, C. E. L., Tsigaridis, K., Vignati, E., Stephanou, E. G., and Wilson, J.: Organic aerosol and global climate modelling: a review, Atmos. Chem. Phys., 5, 1053-1123, https://doi.org/10.5194/acp-5-10532005, 2005 .

Laskin, A., Laskin, J., and Nizkorodov, S. A.: Chemistry of Atmospheric Brown Carbon, Chem. Rev., 115, 4335-4382, https://doi.org/10.1021/cr5006167, 2015.

Leaitch, W. R., Sharma, S., Huang, L., Toom-Sauntry, D., Chivulescu, A., Macdonald, A. M., von Salzen, K., Pierce, J. R., Bertram, A. K., Schroder, J. C., Shantz, N. C., Chang, R. Y.W., and Norman, A.-L.: Dimethyl sulfide control of the clean summertime Arctic aerosol and cloud, Elementa, 1, 000017, https://doi.org/10.12952/journal.elementa.000017, 2013.

Leaitch, W. R., Russell, L. M., Liu, J., Kolonjari, F., Toom, D., Huang, L., Sharma, S., Chivulescu, A., Veber, D., and Zhang, W.: Organic functional groups in the submicron aerosol at $82.5^{\circ} \mathrm{N}$, $62.5^{\circ} \mathrm{W}$ from 2012 to 2014, Atmos. Chem. Phys., 18, 32693287, https://doi.org/10.5194/acp-18-3269-2018, 2018.

Levin, I., Naegler, T., Kromer, B., Diehl, M., Francey, R. J., GomezPelaez, A. J., Steele, L. P., Wagenbach, D., Weller, R., Worthy, D. E., and Deihl, M.: Observations and modelling of the global distribution and long-term trend of atmospheric ${ }^{14} \mathrm{CO}_{2}$, Tellus B, 62, 26-46, 2010.

Liggio, J., Li, S. M., Hayden, K., Taha, Y. M., Stroud, C., Darlington, A., Drollette, B. D., Gordon, M., Lee, P., Liu, P., Leithead, A., Moussa, S. G., Wang, D., O’Brien, J., Mittermeier, R. L., Brook, J. R., Lu, G., Staebler, R. M., Han, Y., Tokarek, T. W., Osthoff, H. D., Makar, P. A., Zhang, J., Plata, D. L., and Gentner, D. R.: Oil sands operations as a large source of secondary organic aerosols, Nature, 534, 91-94, https://doi.org/10.1038/nature17646, 2016.

Meredith, W., Ascough, P. L., Bird, M. I., Large, D. J., Snape, C. E., Sun, Y., and Tilston, E. L.: Assessment of hydrprolysis as a method for the qualification of black carbon using standard reference materials, Geochim. Cosmochim. Aci, 97, 131-147, 2012.

Mouteva, G. O., Fahrni, S. M., Santos, G. M., Randerson, J. T., Zhang, Y.-L., Szidat, S., and Czimczik, C. I.: Accuracy and precision of ${ }^{14} \mathrm{C}$-based source apportionment of organic and elemental carbon in aerosols using the Swiss_4S protocol, Atmos. Meas. Tech., 8, 3729-3743, https://doi.org/10.5194/amt-8-37292015, 2015a.

Mouteva, G. O., Czimczik, C. I., Fahrni, S. M., Wiggins, E. B., Rogers, B. M., Veraverbeke, S., Xu, X., Santos, G. M., Henderson, J., Miller, C. E., and Randerson, J. T.: Black carbon aerosol dynamics and isotopic composition in Alaska linked with boreal fire emissions and depth of burn in organic soils, Global Biogeochem. Cy., 29, 1977-2000, https://doi.org/10.1002/2015GB005247, 2015b.

Pöschl, U.: Atmospheric aerosols: Composition, transformation, climate and health effects, Angew. Chem. Int. Edit., 44, 75207540, https://doi.org/10.1002/anie.200501122, 2005.
Putaud, J. P., Van Dingenen, R., Alastuey, A., Bauer, H., Birmili, W., Cyrys, J., Flentje, H., Fuzzi, S., Gehrig, R., Hansson, H. C., Harrison, R. M., Herrmann, H., Hitzenberger, R., Hüglin, C., Jones, A. M., Kasper-Giebl, A., Kiss, G., Kousa, A., Kuhlbusch, T. A. J., Löschau, G., Maenhaut, W., Molnar, A., Moreno, T., Pekkanen, J., Perrino, C., Pitz, M., Puxbaum, H., Querol, X., Rodriguez, S., Salma, I., Schwarz, J., Smolik, J., Schneider, J., Spindler, G., ten Brink, H., Tursic, J., Viana, M., Wiedensohler, A., and Raes, F.: A European aerosol phenomenology - 3: Physical and chemical characteristics of particulate matter from 60 rural, urban, and kerbside sites across Europe, Atmos. Environ., 44, 1308-1320, https://doi.org/10.1016/j.atmosenv.2009.12.011, 2010.

Reimer, P. J., Brown, T. A., and Reimer, R. W.: Discussion: Reporting and calibration of post bomb ${ }^{14} \mathrm{C}$ data, Radiocarbon, 46, 1299-1304, 2004.

Ridley, D. A., Heald, C. L., Ridley, K. J., and Kroll, J. H.: Cause and consequences of decreasing atmeopheric organic aerosol in the United States, P. Natl. Acad. Sci. USA, 115, 290-295, https://doi.org/10.1073/pnas.1700387115, 2018.

Santos, G. M., Moore, R. B., Southon, J. R., Griffin, S., Hinger, E., and Zhang, D.: AMS ${ }^{14} \mathrm{C}$ Sample Preparation at the KCCAMS/UCI Facility: Status Report and Performance of Small Samples, Radiocarbon, 49, 255-269, https://doi.org/10.1017/S0033822200042181, 2007a.

Santos, G. M., Southon, J. R., Griffin, S., Beaupre, S. R., and Druffel, E. R. M.: Ultra small-mass AMS ${ }^{14} \mathrm{C}$ sample preparation and analyses at KCCAMS/UCI Facility, Nucl. Instrum. Meth. B, 259, 293-302, 2007b.

Santos, G. M., Southon, J. R., Drenzek, N. J., Ziolkowski, L. A., Druffel, E. R. M., Xu, X., Zhang, D., Trumbore, S. E., Eglinton, T. I., and Hughen, K. A.: Blank assessment for ultra-small radiocarbon samples, Radiocarbon, 52, 1322-1335, 2010.

Sharma, S., Leaitch, W. R., Huang, L., Veber, D., Kolonjari, F., Zhang, W., Hanna, S. J., Bertram, A. K., and Ogren, J. A.: An evaluation of three methods for measuring black carbon in Alert, Canada, Atmos. Chem. Phys., 17, 15225-15243, https://doi.org/10.5194/acp-17-15225-2017, 2017.

Shrivastava, M., Cappa, C. D., Fan, J., Goldstein, A. H., Guenther, A. B., Jimenez, J. L., Kuang, C., Laskin, A., Martin, S. T., Ng, N. L., and Petaja, T.: Recent advances in understanding secondary organic aerosol: Implications for global climate forcing, Rev. Geophys., 55, 509-559, 2017.

Stuiver, M. and Polach, H. A.: Discussion Reporting of ${ }^{14} \mathrm{C}$ Data, Radiocarbon, 19 , 355-363, https://doi.org/10.1017/S0033822200003672, 1977.

Szidat, S., Jenk, T. M., Gäggeler, H. W., Synal, H.-A., Hajdas, I., Bonani, G., and Saurer, M.: THEODORE, a two-step heating system for the EC/OC determination of radiocarbon $\left({ }^{14} \mathrm{C}\right)$ in the environment, Nucl. Instrum. Meth. B, 223-224, 829-836, 2004.

Szidat, S., Jenk, T. M., Synal, H.-A., Kalberer, M., Wacker, L., Hajdas, I., Kasper-Giebl, A., and Baltensperger, U.: Contributions of fossil fuel, biomass-burning, and biogenic emissions to carbonaceous aerosols in Zurich as traced by ${ }^{14} \mathrm{C}$, J. Geophys. Res., 111, D07206, https://doi.org/10.1029/2005JD006590, 2006.

Trumbore, S. E., Sierra, C. A., and Hicks Pries, C. E.: Radiocarbon Nomenclature, Theory, Models, and Interpretation: Measuring Age, Determining Cycling Rates, and Tracing Source Pools, in: Radiocarbon and Climate Change: Mechanisms, Applications and Laboratory Techniques, edited by: Schuur, E. A. G., Druf- 
fel, E., and Trumbore, S. E., Springer International Publishing, Cham, 45-82, 2016.

Watson, J. G., Chen, L. A., Chang, O., Chow, J. C., Watson, J. G., Chen, L. A., Chang, M. C. O., Robinson, N. F., Trimble, D., and Kohl, S.: The IMPROVE_A Temperature Protocol for Thermal/Optical Carbon Analysis: Maintaining Consistency with a Long-Term Database, Air Waste Manage., 57, 1014-1023, https://doi.org/10.3155/1047-3289.57.9.1014, 2007.

Wex, H., Huang, L., Zhang, W., Hung, H., Traversi, R., Becagli, S., Sheesley, R. J., Moffett, C. E., Barrett, T. E., Bossi, R., Skov, H., Hünerbein, A., Lubitz, J., Löffler, M., Linke, O., Hartmann, M., Herenz, P., and Stratmann, F.: Annual variability of ice-nucleating particle concentrations at different Arctic locations, Atmos. Chem. Phys., 19, 5293-5311, https://doi.org/10.5194/acp-19-5293-2019, 2019.

Wiggins, E. B., Czimczik, C. I., Santos, G. M., Chen, Y., Xu, X., Holden, S. R., Randerson, J. T., Harvey, C. F., Kai, F. M., and Yu, L. E.: Smoke radiocarbon measurements from Indonesian fires provide evidence for burning of millenniaaged peat, P. Natl. Acad. Sci. USA, 115, 12419-12424, https://doi.org/10.1073/pnas.1806003115, 2018.

Willis, M. D., Healy, R. M., Riemer, N., West, M., Wang, J. M., Jeong, C.-H., Wenger, J. C., Evans, G. J., Abbatt, J. P. D., and Lee, A. K. Y.: Quantification of black carbon mixing state from traffic: implications for aerosol optical properties, Atmos. Chem. Phys., 16, 4693-4706, https://doi.org/10.5194/acp16-4693-2016, 2016.

Winiger, P., Andersson, A., Eckhardt, S., Stohl, A., and Gustafsson, O.: The sources of atmospheric black carbon at a European gateway to the Arctic, Nat. Commun., 7, 12772, https://doi.org/10.1038/ncomms12776, 2016.

Winiger, P., Andersson, A., Eckhardt, S., Stohl, A., Semiletov, I. P., Dudarev, O. V., Charkin, A., Shakhova, N., Klimont, Z., Heyes, C., and Gustafsson, Ö.: Siberian Arctic black carbon sources constrained by model and observation, P. Natl. Acad. Sci. USA, 114, E1054-E1061, https://doi.org/10.1073/pnas.1613401114, 2017.

Winiger, P., Barrett, T. E., Sheesley, R. J., Huang, L., Sharma, S., Barrie, L. A., Yttri, K. E., Evangeliou, N., Eckhardt, S., Stohl, A., Klimont, Z., Heyes, C., Semiletov, I. P., Dudarev, O. V., Charkin, A., Shakhova, N., Holmstrand, H., Andersson, A., and Gustafsson, Ö.: Source apportionment of circum-Arctic atmospheric black carbon from isotopes and modeling, Science Advances, 5, eaau8052, https://doi.org/10.1126/sciadv.aau8052, 2019.
Xu, J.-W., Martin, R. V., Morrow, A., Sharma, S., Huang, L., Leaitch, W. R., Burkart, J., Schulz, H., Zanatta, M., Willis, M. D., Henze, D. K., Lee, C. J., Herber, A. B., and Abbatt, J. P. D.: Source attribution of Arctic black carbon constrained by aircraft and surface measurements, Atmos. Chem. Phys., 17, 1197111989, https://doi.org/10.5194/acp-17-11971-2017, 2017.

Xu, X., Trumbore, S. E., Zheng, S., Southon, J. R., McDuffee, K. E., Luttgen, M., and Liu, J. C.: Modifying a sealed tube zinc reduction method for preparation of AMS graphite targets: Reducing background and attaining high precision, Nucl. Instrum. Meth. B, 259, 320-329, https://doi.org/10.1016/j.nimb.2007.01.175, 2007.

Yang, F., Huang, L., Duan, F., Zhang, W., He, K., Ma, Y., Brook, J. R., Tan, J., Zhao, Q., and Cheng, Y.: Carbonaceous species in $\mathrm{PM}_{2.5}$ at a pair of rural/urban sites in Beijing, 2005-2008, Atmos. Chem. Phys., 11, 7893-7903, https://doi.org/10.5194/acp11-7893-2011, 2011a.

Yang, F., Tan, J., Zhao, Q., Du, Z., He, K., Ma, Y., Duan, F., Chen, G., and Zhao, Q.: Characteristics of $\mathrm{PM}_{2.5}$ speciation in representative megacities and across China, Atmos. Chem. Phys., 11, 5207-5219, https://doi.org/10.5194/acp-11-5207-2011, $2011 \mathrm{~b}$.

Zencak, Z., Elmquist, M., and Gustafsson, Ö.: Quantification and radiocarbon source apportionment of black carbon in atmospheric aerosols using the CTO-375 method, Atmos. Environ., 41, 7895-7906, 2007.

Zhang, X., Li, J., Mo, Y., Shen, C., Ding, P., Wang, N., Zhu, S., Cheng, Z., He, J., Tian, Y., Gao, S., Zhou, Q., Tian, C., Chen, Y., and Zhang, G.: Isolation and radiocarbon analysis of elemental carbon in atmospheric aerosols using hydropyrolysis, Atmos. Environ., 198, 381-386, https://doi.org/10.1016/j.atmosenv.2018.11.005, 2019.

Zhang, X. Y., Wang, Y. Q., Zhang, X. C., Guo, W., and Gong, S. L.: Carbonaceous aerosol composition over various regions of China during 2006, J. Geophys. Res., 113, D14111, https://doi.org/10.1029/2007JD009525, 2008.

Zhang, Y. L., Perron, N., Ciobanu, V. G., Zotter, P., Minguillón, M. C., Wacker, L., Prévôt, A. S. H., Baltensperger, U., and Szidat, S.: On the isolation of OC and EC and the optimal strategy of radiocarbon-based source apportionment of carbonaceous aerosols, Atmos. Chem. Phys., 12, 10841-10856, https://doi.org/10.5194/acp-12-10841-2012, 2012. 